\title{
The Envy of Scholars: Applying the Lessons of the Framingham Heart Study to the Prevention of Chronic Kidney Disease
}

\author{
Walter G. Wasser, M.D. ${ }^{1,2}$, Amnon Gil, M.D. ${ }^{3}$, and Karl L. Skorecki, M.D., \\ F.R.C.P.(C), F.A.S.N. ${ }^{2,4,5}$ \\ ${ }^{\prime}$ Division of Nephrology, Mayanei HaYeshua Medical Center, Bnei Brak, Israel; ${ }^{2}$ Division of Nephrology, \\ Rambam Health Care Campus, Haifa, Israel, ${ }^{3}$ Division of Nephrology, Carmel Medical Center, Haifa, \\ Israel; ${ }^{*}$ Ruth $\mathcal{E}^{2}$ Bruce Rappaport Faculty of Medicine, Technion-Israel Institute of Technology, Haifa, \\ Israel; and ${ }^{5}$ Director of Medical and Research Development, Rambam Health Care Campus, Haifa, Israel.
}

\begin{abstract}
During the past 50 years, a dramatic reduction in the mortality rate associated with cardiovascular disease has occurred in the US and other countries. Statistical modeling has revealed that approximately half of this reduction is the result of risk factor mitigation. The successful identification of such risk factors was pioneered and has continued with the Framingham Heart Study, which began in 1949 as a project of the US National Heart Institute (now part of the National Heart, Lung, and Blood Institute). Decreases in total cholesterol, blood pressure, smoking, and physical inactivity account for $24 \%, 20 \%, 12 \%$, and $5 \%$ reductions in the mortality rate, respectively. Nephrology was designated as a recognized medical professional specialty a few years later. Hemodialysis was first performed in 1943. The US Medicare End-Stage Renal Disease
\end{abstract}

Citation: Wasser WG, Gil A, Skorecki KL. The Envy of Scholars: Applying the Lessons of the Framingham Heart Study to the Prevention of Chronic Kidney Disease. Rambam Maimonides Med J 2015;6 (3):eoo29. doi:10.5041/RMMJ.10214

Copyright: (C) 2015 Wasser et al. This is an open-access article. All its content, except where otherwise noted, is distributed under the terms of the Creative Commons Attribution License (http://creativecommons.org/licenses/by/3.0), which permits unrestricted use, distribution, and reproduction in any medium, provided the original work is properly cited.

Acknowledgement: The authors are indebted to Dr Barry M. Brenner whose many lectures and discussions find themselves reflected in the content of this article. The authors are also grateful to Margie Serling Cohn, Head Librarian of the Alfred Goldschmidt Medical Sciences Library of the Ruth and Bruce Rappaport Faculty of Medicine, Technion-Israel Institute of Technology, for her continuous support to us over many years in locating many of the articles and reference materials required in the pursuit of scholarly activity. We wish her best of luck on her forthcoming retirement.

Conflict of interest: No potential conflict of interest relevant to this article was reported.

* To whom correspondence should be addressed. E-mail: Lcdialysis@aol.com 
(ESRD) Program was established in 1972. The number of patients in the program increased from 5,00o in the first year to more than 500,000 in recent years. Only recently have efforts for risk factor identification, early diagnosis, and prevention of chronic kidney disease (CKD) been undertaken. By applying the approach of the Framingham Heart Study to address CKD risk factors, we hope to mirror the success of cardiology; we aim to prevent progression to ESRD and to avoid the cardiovascular complications associated with CKD. In this paper, we present conceptual examples of risk factor modification for CKD, in the setting of this historical framework.

KEY WORDS: ACE inhibitor, chronic kidney disease, FGF23, proteinuria, risk-factors

Rav Dimi from the Babylonian Talmudic Academy of Nehardea said: "Jealousy between scholars increases wisdom.”

Babylonian Talmud, Tractate Bava Batra 21a

\section{INTRODUCTION: CONTRASTING CARDIOLOGY AND NEPHROLOGY}

Over the last half century, we have witnessed a global reduction in the coronary heart disease mortality rate by approximately $60 \%$ (Figure 1 ). ${ }^{1}$ Cardiovascular disease mortality rates in the US dramatically decreased from 805 deaths per 100,000 people in 1963 to 236 per 100,000 people in 2010.2 Before that time, the incidence of cardiovascular disease-related death was on the rise. Myocardial infarction and sudden death would occur without warning, striking down individuals in mid-life, during the peak of their productivity. ${ }^{3}$ In addition, the pathophysiology of these disorders was not understood.

It was in this context that the US National Heart Institute launched and co-ordinated the Framingham Heart Study in 1949. This study would become a cornerstone in cardiac epidemiology, heralding numerous follow-up studies in different constitu- encies and formats. The study, which began with 5,209 patients who were followed longitudinally, is still ongoing and has enrolled three generations of participants. The analysis gave rise to the concept of risk factors for coronary disease, including hypertension, high cholesterol, and smoking. This recognition led to vigorous risk-reduction campaigns. $4^{-6}$

Models of the decrease in cardiac mortality from 1980 to 2000 found that risk factor reduction explained $44 \%$ of the reduction in cardiac death; treatment was responsible for an additional 47\% reduction in mortality. Furthermore, reductions in total cholesterol, blood pressure, smoking, and physical inactivity accounted for $24 \%, 20 \%, 12 \%$, and $5 \%$ reductions in the mortality rate, respectively. 7

Cardiovascular risk prediction formulae, which are important for gauging individual cardiovascular risk, are also useful for understanding populationwide coronary disease risk. ${ }^{1,8}$ The Framingham risk estimation system, the most commonly used tool for

\footnotetext{
Abbreviations: ACCORD, Action to Control Cardiovascular Risk in Diabetes; ACR, albumin-creatinine ratio; ADVANCE, Action in Diabetes and Vascular Disease Trial; AKI, acute kidney injury; AIPRD, ACE Inhibition in Progressive Renal Disease; ALLHAT Antihypertensive and Lipid Lowering Treatment to Prevent Heart Attack Trial; ALTITUDE, Aliskiren Trial in Type II Diabetes Using Cardiorenal Endpoints; ARB, angiotensin receptor blocker; ATI, angiotensin II type 1; ATII angiotensin II type 2; CKD, chronic kidney disease; COMBINE, CKD Optimal Management with Binders and Nicotinamide; DCCT/EDIC, Diabetes Control and Complications Trial/Epidemiology of Diabetes Interventions and Complications; ESRD, end-stage renal disease; FGF23, fibroblast growth factor 23; GFR, glomerular filtration rate; IIH, idiopathic infantile hypercalcemia; KDIGO, Kidney Disease: Improving Global Outcomes; LVH, left ventricular hypertrophy; MDRD, Modification of Diet in Renal Disease; MRFIT, Multiple Risk Factor Intervention Trial; ONTARGET, Renal Outcomes with Telmisartan, Ramipril, or Both in People at High Vascular Risk Study; RAAS, renin-angiotensin-aldosterone system; NHANES, National Health and Nutrition Examination Survey III; REIN, Ramipril Efficacy in Nephropathy; RENAAL, Reduction of End Points in NIDDM with the Angiotensin II Receptor Antagonist Losartan; SEEK, Study to Evaluate Early Kidney Disease; T2DM, type 2 diabetes mellitus; UKPDS, The United Kingdom Prospective Diabetes Study; VALID, Preventing ESRD in Overt Nephropathy of Type 2 Diabetes; VA NEPHRON-D, Diabetes in Nephropathy Study, Combination Angiotensin Receptor Blocker and Angiotensin Converting Enzyme Inhibitor for Treatment of Diabetic Nephropathy.
} 


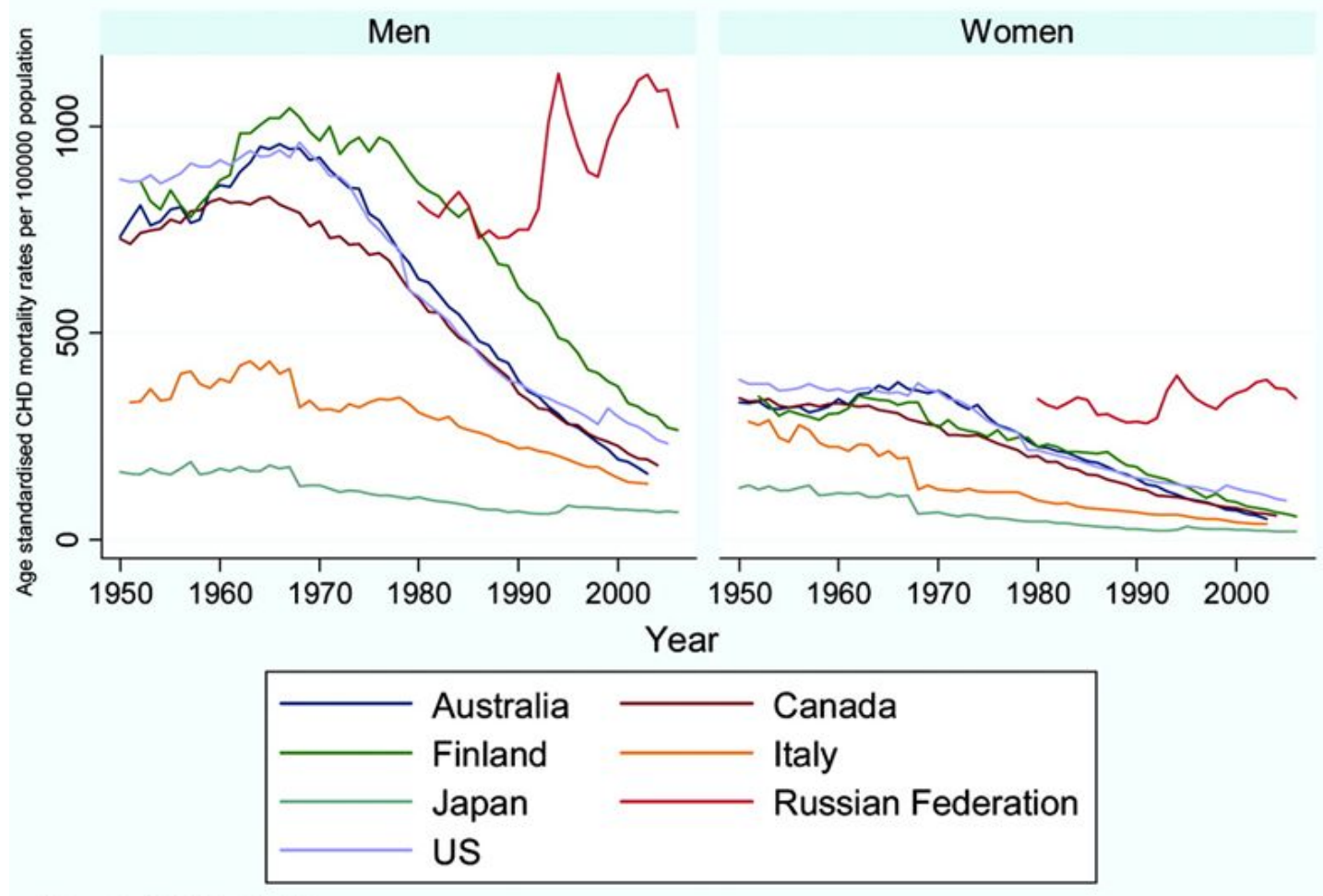

Source: WHO website

Figure 1. Global Age-standardized Coronary Heart Disease (CHD) Mortality Rates in Men and Women 45 to 74 Years of Age, Based on World Health Organization Statistics.

Copyright 2010, Wolters Kluwer Health, Inc. Used with permission from Cooney et al. ${ }^{1}$ Promotional and commercial use of the material in print, digital or mobile device format is prohibited without the permission from the publisher Wolters Kluwer Health.

this purpose, has been adjusted for use in various countries and was developed via cardiac epidemiological studies. Research is presently underway to incorporate sets of single-nucleotide polymorphisms (SNPs) obtained from genome-wide association studies (GWAS) to increase the accuracy of coronary heart disease risk determination. 9

Paralleling these developments, clinicians who received scientific fellowship training in the laboratories of renal physiologists returned to their academic internal medicine departments to create divisions of nephrology.10 These departments supported active research on renal physiology while also providing clinical care to nephrology patients. ${ }^{11}$ The first kidney biopsies were performed in the 1950 . Although hemodialysis was first performed in 1943, it was typically performed outside of these departments because the procedure was viewed in many centers as academically unworthy..$^{10}$ Kidney transplantation was first developed in $1963 .{ }^{12}$ The pro- vision of dialysis therapy to people with kidney disease challenged the young specialty. Hemodialysis initially lacked specific funding, and committees such as the Admissions and Policies Committee of the Seattle Artificial Kidney Center at Swedish Hospital determined which patients would receive treatment. ${ }^{13}$ Such groups, consisting of seven citizens selected by The Kings County Medical Society, were formed to prevent doctors from needing to make these decisions regarding their own patients. Although the deliberations of the "God committee" were secret, a prominent article in Life Magazine detailing the thinking involved did emerge. ${ }^{13}$

The idea of federal funding for end-stage renal disease (ESRD) was debated among clinicians, and a vocal minority backed Boston nephrologist Dr Norman Levinsky who wrote in the influential New England Journal of Medicine in August 1964 that "both chronic dialysis and transplantation ... are properly considered clinical experiments rather than 
established modes of treatment at this time."14 Dramatically, in October, 1971, Shep Glazer, then Vice President of the National Association of Patients on Hemodialysis testified before the House Ways and Means Committee while being dialyzed. In 1972, congressional approval was attained to expand funding for the Medicare dialysis program; soon afterward, nearly every nephrology division embraced dialysis. The creation of the ESRD Program as part of the Medicare program for patients of any age who required dialysis tasked nephrologists with the substantial job of providing dialysis treatments, an endeavor that overwhelmed, hindered, and did not provide incentives for the performance of epidemiologic research for the identification and mitigation of risk factors in order to reduce the onset and progression of chronic kidney disease (CKD). Physiological research regarding the pathogenesis of chronic kidney disease led to new treatments for patients and a vital taxonomy of kidney diseases; however, it did not significantly influence the treatment of the majority of individuals with CKD. Over the next 60 years, the progressive advances in hemodialysis technologies did not affect the dialysis patient 5 -year mortality that remained at $\sim 50 \%$ (a mortality rate just slightly lower than that of lung cancer). ${ }^{15}$

Although the initial estimates of individuals who would require dialysis were low, the number of patients receiving dialysis treatment increased exponentially. From an initial 5,000 patients in 1972, the US ESRD program expanded more than 100-fold to 636,905 patients by $2012 .{ }^{16}$ Today, although 17,330 kidney transplants are performed annually, 81,981 patients remain on the active transplant waiting list, and numerous kidney transplantation candidates die while still on dialysis. ${ }^{16}$

Numerous pathophysiological studies, particularly those conducted by Drs Neal Bricker and Barry Brenner, have led directly to a paradigm shift in the treatment of CKD. Bricker proposed the "trade-off hypothesis," in which he provided evidence that the production of hormonal factors in the setting of chronic renal failure was a homeostatic adaptation and not a consequence of a reduced glomerular filtration rate. ${ }^{17,18}$ As examples, he listed parathyroid hormone (PTH) and natriuretic factor. Bricker postulated that a circulating inhibitor of sodium transport alters the net movement of sodium from tubular fluid to the blood; recently this factor was purported to have been isolated. ${ }^{19}$
Brenner and colleagues showed that intraglomerular hypertension increases in residual nephrons following nephron loss. Systemic hypertension also increases intraglomerular pressure, which is modulated by the vascular tone of the pre- and postglomerular arterioles, intraglomerular architecture, and hemodynamics. Elevated glomerular capillary pressure leads to an increased number of large nonselective pores on the glomerular capillary wall, which promotes proteinuria. ${ }^{20-22}$ Growth-promoting factors are released in the remnant glomeruli, and these factors produce excessive extracellular matrix in the mesangial area, obliterating the capillary lumen and creating typical sclerotic lesions. Nephron loss is increased, and this effect augments these processes in other glomeruli. ${ }^{22}$ Glomerular hypertrophy in remnant nephrons, compensatory to nephron loss, also contributes to glomerular sclerosis. The latter effect was reduced in a rat model of nephron loss without hypertrophy, compared with five-sixths of nephrectomized rats with a higher glomerular area, despite similar elevations in intraglomerular pressure.23 Brenner and colleagues showed that the inhibition of the vasoconstricting effect of angiotensin II via angiotensin-converting enzyme (ACE) inhibitors, which is most pronounced at the level of the post-glomerular arterioles, reduces intraglomerular hydraulic pressure. The effect of these agents on kidney injury progression supports the association between high glomerular pressure and sclerosis. In addition, angiotensin II inhibition reduces the synthesis of reactive oxygen species, inflammatory cytokines, cell adhesion molecules, and pro-fibrotic molecules such as TGF $\beta .{ }^{24}$

\section{KIDNEY DISEASE AS A PUBLIC HEALTH CONCERN}

As the number of patients receiving dialysis care escalated, the potential associated costs began to alarm health care planners. In the words of the Kidney Disease: Improving Global Outcomes (KDIGO) 2009 Conference Report, the "rising prevalence, poor outcomes, and high costs of chronic kidney disease has led to its recognition as a public health threat." 25 Fundamentally, this recognition represented a paradigm shift for nephrologists and transformed kidney failure from a lifethreatening condition that affected a few people (although these few required dialysis and transplantation) to a common condition that is the target of prevention, early detection, and management by 
Composite ranking for relative risks by GFR and albuminuria (KDIGO 2009)
Albuminuria stages, description and range $(\mathrm{mg} / \mathrm{g})$

\begin{tabular}{|c|c|c|c|c|}
\hline \multicolumn{2}{|c|}{ A1 } & A2 & \multicolumn{2}{|c|}{ A3 } \\
\hline \multicolumn{2}{|c|}{$\begin{array}{l}\text { Optimal and } \\
\text { high-normal }\end{array}$} & High & \multicolumn{2}{|c|}{$\begin{array}{c}\text { Very high and } \\
\text { nephrotic }\end{array}$} \\
\hline$<10$ & $10-29$ & $30-299$ & $\begin{array}{c}300- \\
1999\end{array} \quad \geqslant 2000$ \\
\hline
\end{tabular}

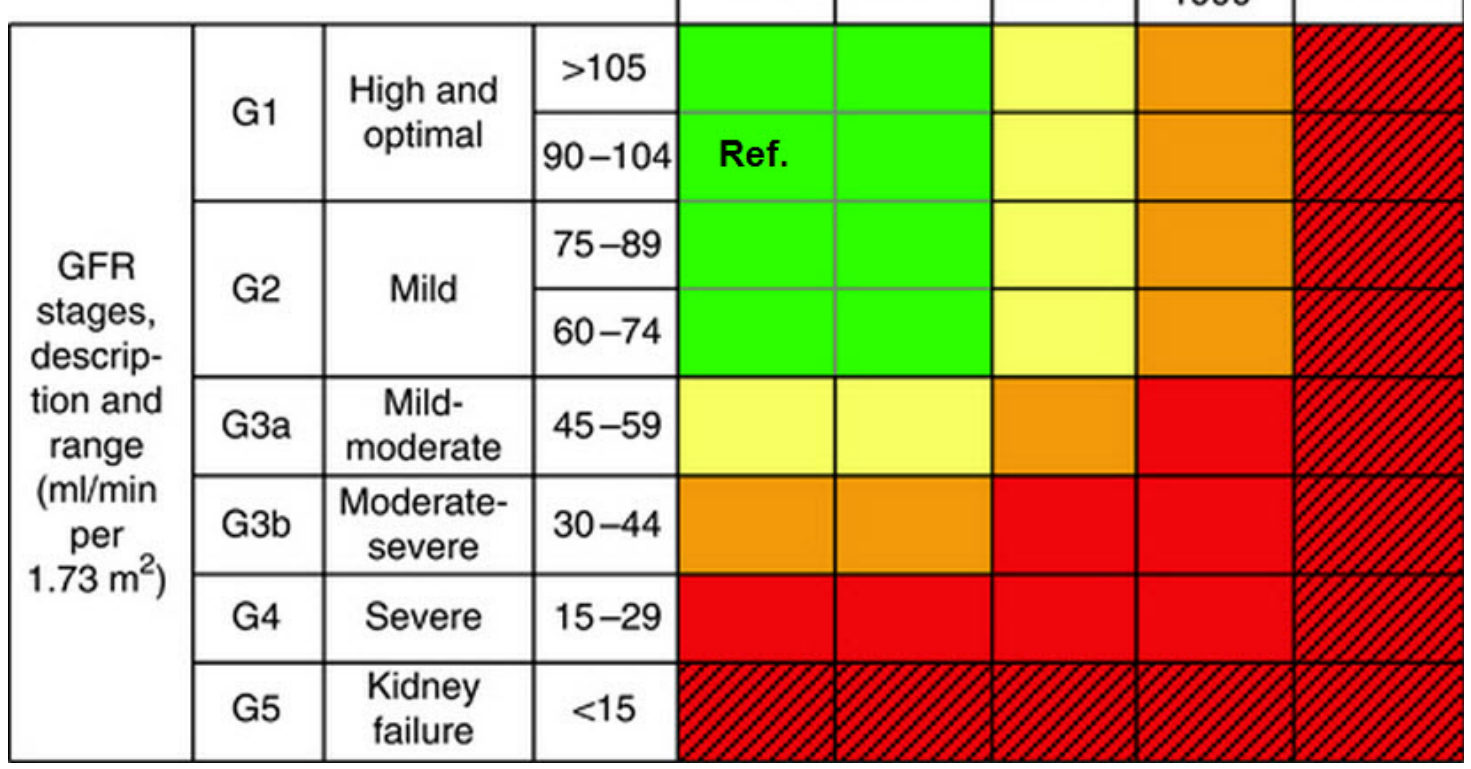

Figure 2. Composite Ranking for Relative Risks by Glomerular Filtration Rate (GFR) and Albuminuria.

Mortality is reported for general population cohorts assessing albuminuria as urine albumin-creatinine ratio (ACR). Kidney outcomes are reported for general population cohorts assessing albuminuria as either urine ACR or dipstick. Estimated glomerular filtration rate (eGFR) and albuminuria are expressed as categorical variables. All results are adjusted for covariates and compared with the reference cell (Ref). Each cell represents a pooled relative risk from a meta-analysis.

Incidence rates per 1,000 person-years (calculated from the reference cells) are 7.0 for all-cause mortality, 4.5 for cardiovascular disease mortality, 0.04 for kidney failure, 0.98 for acute kidney injury (AKI), and 2.02 for kidney disease progression. Absolute risk can be computed by multiplying the relative risks in each cell by the incidence rate in the reference cell. See Levey et al. ${ }^{25}$ for full details.

Colors on this heat map reflect the ranking of adjusted relative risk. The point estimates for each cell were ranked from 1 to 28 (the lowest RR having rank number 1, and the highest number 28). The categories with rank numbers 1 8 are green, rank numbers 9-14 are yellow, the rank numbers 15-21 are orange, and the rank numbers 22-28 are colored red. Color for twelve additional cells with diagonal hatch marks is extrapolated based on results from the meta-analysis of chronic kidney disease cohorts and represents the highest risk. The highest level of albuminuria is termed 'nephrotic' to correspond with nephrotic range albuminuria and is expressed here as 2000 mg/g.

Figure and legend reprinted by permission from Macmillan Publishers Ltd: Kidney International, ${ }^{25}$ copyright 2011.

non-nephrologist physicians and public health agencies. ${ }^{26}$ As a result, a quiet but significant revolution took place, beginning with the description of the model currently in use for CKD (Figure 2). This model spearheaded a redefinition of the diagnosis and treatment of CKD that relied on functional measures and the classification of kidney dysfunction via the degrees of albuminuria and nephron function loss (measured by estimated glomerular filtration rate, eGFR). The overwhelming numbers of patients with $\mathrm{CKD}$ has led nephrologists to follow cardiologists in using a Framingham-like model to identify the risk factors for CKD. 


\section{CHRONIC KIDNEY DISEASE AS A MAJOR CARDIOVASCULAR RISK FACTOR}

The association between ESRD and accelerated cardiovascular mortality has long been recognized. ${ }^{27}$ Mogensen first described microalbuminuria as a cardiovascular risk factor in people with diabetes. ${ }^{28}$ Bigazzi et al. showed the importance of microalbuminuria in predicting cardiovascular risk among people with hypertension. ${ }^{29}$ Recent meta-analyses have demonstrated the continuous associations among macroalbuminuria, microalbuminuria, coronary risk, ${ }^{30}$ and stroke. ${ }^{31}$ Other studies have shown that the use of renin-angiotensin-aldosterone system (RAAS) agents to decrease protein excretion can effectively reduce coronary risk. ${ }^{32-36}$

In line with these findings, screening $60 \%$ of the patients at highest risk has prevented virtually all forms of cardiovascular disease. 37,38 However, elderly patients present "reverse metabolic syn- drome" 39,40 in which lipid levels and blood pressure are reduced, thereby making screening for coronary disease challenging. Detection techniques such as ultrasound measurement of the carotid intimamedia thickness and CT scanning of the coronary arteries to show calcifications might accurately reveal subclinical atherosclerosis; however, these techniques are costly and therefore often unavailable. Estimated GFR and urinary albumin excretion might provide a cost-effective method to identify precisely the patients with cardiovascular disease.

Small increases in serum creatinine are associated with cardiovascular events and mortality. ${ }^{41,42}$ Go and colleagues studied the health records of $\sim 1.1$ million adults in the Kaiser Permanente Renal Registry between 1996 and 2000 for >2 years and found an impressively graded association between estimated GFR and the risks for death, cardiovascular events, and hospitalization (Figure 3). 43 Protein-
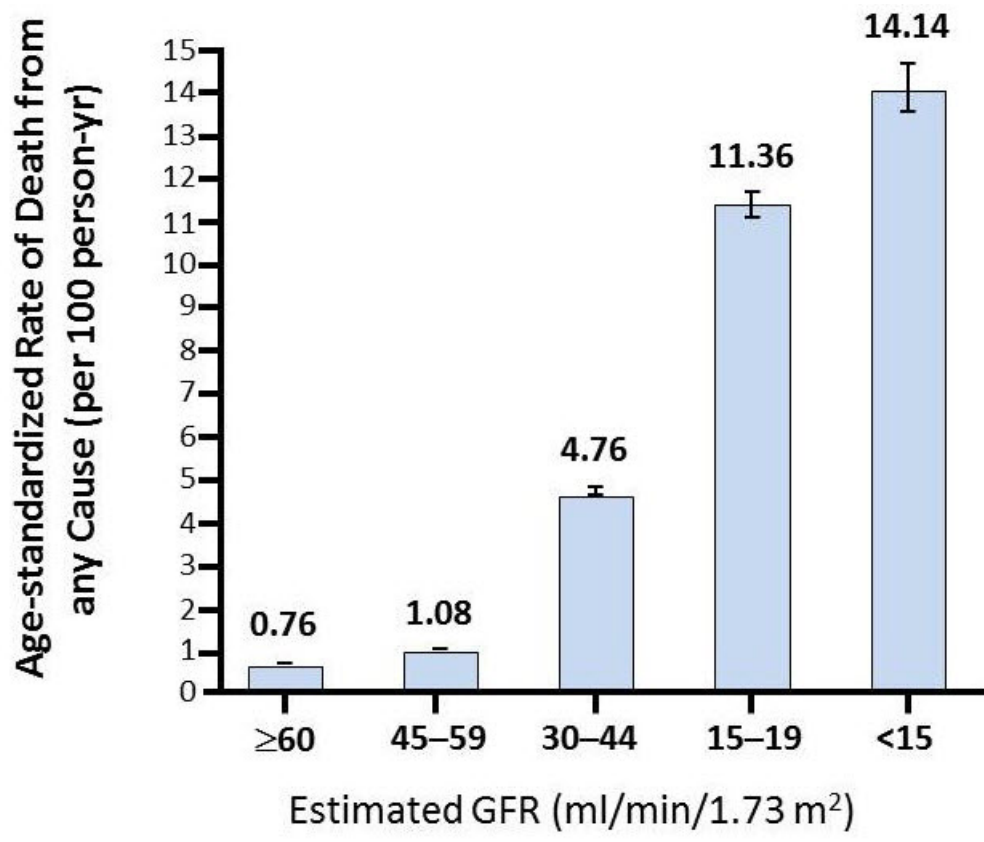

\section{No. of Events: $25,803 \quad 11,569 \quad 7,802 \quad 4,408 \quad 1,842$}

Figure 3. Death from Any Cause According to the Estimated GFR among 1,120,295 Ambulatory Adults.

Among a large, diverse population of adults from Kaiser Permanente Renal Registry, a reduced estimated GFR was associated with increased risks of death, cardiovascular events, and hospitalization that were independent of known risk factors, a history of cardiovascular disease, and the presence of documented proteinuria. These graded risks of adverse events rose sharply for subjects with an estimated GFR of $<45 \mathrm{~mL}$ per minute per $1.73 \mathrm{~m}^{2}$ for each outcome examined both in the overall cohort and in subgroup analyses. Furthermore, in this cohort as a whole, the absolute rates of these outcomes were considerably higher than the risk of end-stage renal disease.

From Go AS et al. ${ }^{43}$ Copyright $\odot 2004$, Massachusetts Medical Society. Reprinted with permission from Massachusetts Medical Society. 
uria was an independent risk factor for death. Chronic kidney disease, as determined via the combination of decreased renal function (estimated GFR) and markers of kidney damage (proteinuria), accurately predicted cardiac events and death more effectively than each individual risk factor alone. ${ }^{44-47}$ Foley and associates recently showed that the use of a "near-normal" estimated GFR cut-off of 94 $\mathrm{mL} / \mathrm{min}$ and an albumin-creatinine ratio (ACR) of 9 $\mathrm{mg} / \mathrm{g}$, rather than the standard CKD thresholds, is highly sensitive and specific for selecting participants at risk of dying over the ensuing 9 years..$^{8}$ Similarly high thresholds for estimated GFR without albuminuria successfully predicted cardiac death in two additional studies.49,50

Cardiovascular disease in the setting of CKD requires recognition and active treatment. Most patients with CKD succumb to cardiovascular disease rather than kidney disease. Recent metaanalyses 51,52 and KDIGO guidelines 53 recommend the use of statin therapy for patients with CKD but not those receiving dialysis.

\section{RISK FACTORS FOR PROGRESSIVE CKD}

The effort to reduce CKD began with therapy for proteinuria and hypertension, which are recognized risk factors for CKD.54,55 The rate of progressive renal deterioration has a linear relationship with blood pressure treated by anti-hypertensive agents..$^{6}$ Large controlled trials have documented the protein reduction properties of effective antihypertensive therapy. ${ }^{5-59}$ The success in implementing these therapies led to the identification of other CKD risk factors.

\section{Proteinuria}

The relationship between reduced proteinuria and progressive renal disease was first demonstrated in the Modification of Diet in Renal Disease (MDRD) Study in 1995,55 which also showed that patients with high urinary protein excretion benefit more from ACE inhibitor-based therapies.55 The inhibition of the RAAS either via ACE inhibitors or angiotensin receptor blockers (ARBs) reduces proteinuria and progressive renal deterioration in excess of what would be expected based on the reduction of blood pressure alone with other non-RAAS agents. ${ }^{60}$ The ACE Inhibition in Progressive Renal Disease (AIPRD) study, a cumulative meta-analysis of 11 clinical trials including the Ramipril Efficacy in Nephropathy (REIN) study, found a strong correla- tion between proteinuria and the decline rate of glomerular filtration rate (GFR) in patients with CKD. ${ }^{61}$ Together, the MDRD and AIPRD studies revealed an impressive $40 \%$ reduction in the risk of doubling serum creatinine concentrations with ACE inhibitor treatment compared with other antihypertensive drugs in patients with CKD with protein levels $>0.5 \mathrm{~g}$ per day. ${ }^{62} \mathrm{~A}$ similar effect was shown in patients with type 1 diabetes undergoing captopril treatment. ${ }^{6}$

The Reduction of End Points in NIDDM with the Angiotensin II Receptor Antagonist Losartan (RENAAL) study found that baseline albuminuria was the strongest predictor of the primary composite end-point of doubling of serum creatinine, end-stage renal disease (ESRD), or death in patients with type 2 diabetes mellitus (T2DM) with a serum creatinine level of $1.5-3.0 \mathrm{mg} / \mathrm{dL} .34$ Overt proteinuria or microalbuminuria predicted kidney deterioration in a population with a high prevalence of $\mathrm{CKD}, 64$ individuals with hypertension and diabetes, and the general population. ${ }^{29,65,66}$ Significantly lower persistent microalbuminuria (6\% in 3 years) was observed in patients with hypertension and T2DM with normal albuminuria treated by trandolapril compared to those receiving placebo $(10 \%)$ or verapamil (11.9\%). ${ }^{67}$ The anti-proteinuric and renal protection provided by ACE inhibitors was also observed in patients with diabetes and normal blood pressure but without microalbuminuria. The increase of albuminuria, even within the normal range, and the decrease of creatinine clearance were significantly lower in patients receiving enalapril compared with those receiving a placebo. ${ }^{68}$

The theoretical added therapeutic benefit of ARBs emanates from the blockage of angiotensin II to the angiotensin type 1 (ATI) receptor interactions as well as through enhanced angiotensin II binding to the vasodilatory angiotensin type 2 (ATII) receptors. ${ }^{69}$ Albuminuria decreased by $28 \%$ among losartan-treated patients over the first 6 months of the RENAAL study compared with a $4 \%$ increase among the placebo group. The decrease in albuminuria in the losartan group was associated with improved kidney function, going beyond the drug's blood pressure-lowering effect. ${ }^{34}$ Changes in albuminuria showed an approximately linear relationship with the degree of long-term kidney protection. In particular, every 50\% reduction in albuminuria was associated with a corresponding $\sim 36 \%$ reduction in the risks of doubling of serum creatinine level, stage $5 \mathrm{CKD}$, or death. A similar effect was ob- 
served regarding other ARBs ${ }^{32,70}$ such as irbisartan. Treatment with ARBs has also been successful in patients with incipient diabetic nephropathy. .7172 $^{7}$ The anti-albuminuric and renal protective effects of ARBs are similar, although slightly weaker, than the corresponding effects of the ACE inhibitors in early diabetic nephropathy. 73

Despite the enormous progress that has been made in the treatment of progressive kidney disease via RAAS inhibition, the residual kidney risk after treatment with an ACE inhibitor or an ARB remains high and is associated with residual albuminuria.74,75 For example, in the RENAAL trial, losartan reduced the 3-year risk of doubling serum creatinine levels from $47 \%$ to $44 \% .33$ In light of these high residual risk rates, recent reviews have examined various new strategies to enhance the effects of RAAS blockade. ${ }^{69,76}$ The RAAS is an endocrine cascade system that can be inhibited at many levels, but it can be compensated for at other levels with a clinical response known as “escape.” 69,76

Clinical trials have examined the use of the combination of an ACE inhibitor and an ARB to prevent target organ damage. 77 The Renal Outcomes with Telmisartan, Ramipril, or Both in People at High Vascular Risk (ONTARGET) trial compared the ACE inhibitor ramipril with the ARB telmisartan, alone and in combination, among patients at high risk for vascular disease. ${ }^{78,79}$ Although the achieved mean blood pressure was lower in patients who received telmisartan or both agents than in those who received ramipril alone, no difference was observed with regard to the primary outcomes among any of the groups, and more adverse outcomes were noted in the combination group. Importantly, this trial did not evaluate ARB and ACE inhibitor therapy in patients with advanced proteinuric renal disease. The VA Nephron-D Diabetes in Nephropathy Study (VA NEPHRON-D), a trial using a combination therapy (i.e. ACE inhibitor and ARB therapy versus ARB monotherapy) in patients with proteinuric diabetic nephropathy, was stopped because of the increased adverse events of hyperkalemia and acute kidney injury (AKI). ${ }^{80}$ The Aliskiren Trial in Type II Diabetes Using Cardiorenal Endpoints (ALTITUDE) randomly assigned 8,561 patients to aliskiren (300 $\mathrm{mg}$ daily) or a placebo as an adjunct to ACE/ARB monotherapy as an angiotensin receptor blocker. The trial was stopped prematurely because of adverse events (hyperkalemia and hypotension). ${ }^{81}$ Therefore, ACE inhibitors should not be used concomitantly with
ARBs and renin inhibitors because of the increased risks for hypotension, hyperkalemia, and renal dysfunction. ${ }^{82}$

Many studies have attempted to achieve additional benefit from ACE inhibitors and other renin-angiotensin-aldosterone-blocking agents by increasing their dosages. This reasoning is based on the original observation that the optimal antiproteinuric dose is not necessarily equal to the optimal antihypertensive dose. Many of these results have shown additional proteinuria reduction, ${ }^{83-87}$ whereas others have not. ${ }^{88-90}$ However, similar to the initial studies regarding combination therapy with renin-angiotensin-aldosterone-blocking agents, many of these high-dosage studies are also shortterm examinations using blood pressure and albuminuria as outcome variables. These studies have not had sufficient power, and lack the duration needed to detect the safety signals and side effects rates that might emerge from end-point trials. ${ }^{82}$ Therefore, before ultrahigh RAAS-blocking agent dosing can be recommended as a renoprotective therapy, further study of these drugs with kidney and cardiovascular event data is needed. ${ }^{82}$

Optimization strategies for RAAS blockade have been suggested. First, a combination of sodium restriction and diuretic therapy is required to reach optimal RAAS inhibition in proteinuric patients. ${ }^{91-96}$ Second, hyperkalemia, which limits the use of RAAS agents, has recently received effective treatment with patiromer and sodium zirconium cyclosilicate among outpatients. ${ }^{97,98}$ These two novel drugs add to the pharmacopoeia that until recently was limited to sodium and calcium polystyrene sulfonate, which have adverse gastrointestinal effects.

Importantly, a few clinical caveats exist when treating proteinuria with RAAS inhibitors. First, greater initial decreases of renal function predict longer preservation of renal function. 99 An initial loss of estimated GFR is not a concern unless it exceeds $30 \%$, at which point diuretic-induced hypovolemia and renal artery stenosis should be considered. ${ }^{100}$ In addition, the importance of monitoring urinary albumin decreases following RAAS blockade. ${ }^{101}$ If the urinary albumin-creatinine ratio is not lowered by $\geq 30 \%$ or to $<300 \mathrm{mg} / \mathrm{g}$ despite a blood pressure lower than 130/80 combined with a lowsodium diet, then switching to another RAAS blocker or diltiazem should be considered.79,102 Greater reductions in proteinuria are seen with treatment using non-dihydropyridine calcium channel blockers (CCBs) than with dihydropyridine CCBs. ${ }^{102}$ 


\section{RAAS Inhibitors for Cardiovascular Protection}

The ACE inhibitors reduce the rates of death, myocardial infarction, stroke, and heart failure among patients with heart failure, ${ }^{103}$ left ventricular dysfunction, ${ }^{104}$ previous vascular disease, ${ }^{105}$ and/or high-risk diabetes. ${ }^{106}$ The ARBs are an alternative for patients who cannot tolerate ACE inhibitors Although ACE inhibitors and ARBs have an additive effect, the more effective indication is to combine ACE inhibitor therapy with an aldosterone antagonist.

The MDRD study and other clinical interventions demonstrated strong interactions among proteinuria, hypoalbuminemia, blood pressure, CKD progression, and an increase in the inflammatory state.55,107 Furthermore, microalbuminuria is an independent risk factor for cardiovascular disease. In patients with T2DM, an albuminuria level of 20.1-30 mg/d was associated with a relative risk for cardiovascular disease of 9.8, and the relative risk for microalbuminuria was 12.4 compared with patients with albuminuria levels below $10 \mathrm{mg} / \mathrm{d} .108$ The beneficial effect of albuminuria reduction for cardiovascular outcomes is likely associated with improvements in endothelial function in addition to the indirect effect mediated through the mitigation of renal dysfunction.

The ONTARGET trial assessed cardiovascular morbidity in patients with cardiovascular disease or high-risk diabetes but without significant albuminuria. Similar beneficial effects were observed regarding $\mathrm{ARBs}$ as $\mathrm{ACE}$ inhibitors for cardioprotection. However, the combination of these agents with $\mathrm{ACE}$ inhibitors was not associated with an increase in cardiac benefit, whereas adverse events were more common.79

\section{Hypertension}

Hypertension is an uncontrolled and global public health challenge that is equally prevalent in developed and developing nations. ${ }^{109}$ In 2000, 25\% of the world's population had hypertension; however, approximately 29\% (1.56 billion people) are expected to have hypertension by 2025 . This increase has been ascribed to the massive "epidemiologic transition" of the developing world, with increasing proportions of elderly populations. ${ }^{110,111}$ Hypertension is the leading cause of cardiovascular morbidity and mortality and a major cause of CKD.
Perry et al. were one of the earliest groups to document carefully the association between increasing levels of systolic blood pressure, cardiovascular disease, and CKD risk. ${ }^{112}$ They described the direct association between increments in blood pressure elevation and the development of renal failure in 11,912 male veterans, $48 \%$ of whom were AfricanAmericans, followed for 15 years at Veterans Administration Hypertension clinics during the mid-1970s. The risk ratios for a systolic blood pressure of 165$180 \mathrm{mmHg}$ and of $>180 \mathrm{mmHg}$ were 2.8 and 7.6, respectively. Hospitalization for myocardial infarction doubled the risk for this disease; congestive heart failure increased the risk 5 -fold and increased the rate of subsequent ESRD. The ESRD rate decreased by two-thirds among individuals whose systolic blood pressure fell by $20 \mathrm{mmHg} .{ }^{112}$ In addition, an increased risk of ESRD was associated with African ancestry (risk ratio=2.2).

The Multiple Risk Factor Intervention Trial (MRFIT) examined the development of cardiovascular complications in 12,000 men over 16 years and found that elevations in baseline systolic blood pressure were correlated with the development of ESRD, even within the high-normal and mild hypertensive ranges. ${ }^{113}$ This study also showed that effective blood pressure control stabilized or improved kidney function in Caucasians but not in AfricanAmericans. ${ }^{114}$ In a 25-year observational study of 177,570 men and women, Hsu et al. demonstrated that small increases in systolic blood pressure within the pre-hypertensive and mild hypertensive ranges were correlated with increased CKD risk over time and an increase in the number of patients with ESRD. ${ }^{115}$ One risk factor for ESRD was high blood pressure (hazard ratio (HR) 2.94, 95\% CI 2.21-3.92 for stage 2 hypertension; HR 2.33, 95\% CI 1.78-3.05 for stage 1 hypertension; and HR 1.72, 95\% CI 1.322.24 for pre-hypertension versus normal).

Forman and Brenner reviewed the evidence regarding a response to aggressive blood pressure reduction in "normotensive" individuals at high risk (diabetes, coronary artery disease, and cerebrovascular disease) and suggested maintaining a blood pressure below $120 / 80$ in these patients. ${ }^{116}$ However, the clinical trials such as the ACCORD study, ${ }^{117}$ the Irbesartan Diabetic Nephropathy Trial (IDNT), ${ }^{118}$ and the International Verapamil SRTrandolaptil Study (INVEST) ${ }^{119}$ found no benefit in bringing the blood below 130/80. Tight control of systolic blood pressure in the latter two studies did 
not yield improved cardiovascular outcomes and was in fact associated with an increase in all-cause mortality. These results have been summarized in other papers. ${ }^{120,121}$

Whether kidney and cardiovascular risks are lower in non-diabetic patients with CKD and blood pressures $<130 / 80$ compared with $<140 / 90$ remains unclear. This issue was examined by four randomized trials, $56,59,122,123$ two of which failed to show a significant benefit.59,122 However, the MDRD study showed that a reduction in blood pressure from $<140 / 90$ to $<125 / 75$ reduced the risk of kidney disease progression (HR o.68) after 10 years of reduced blood pressure. $5^{6}$ Similarly, strict mean arterial blood pressure control in children below the 5oth percentile for age versus a conventional therapy that corresponded to the 5oth to 9oth percentile for age led to decreased proteinuria and progression to ESRD (HR 0.65).124 The Cardio-Sis trial also demonstrated a benefit of blood pressure control in non-diabetic patients. Patients in the tight control group $(<130 \mathrm{mmHg})$ developed less left ventricular hypertrophy ( $11 \%$ of 483 patients; odds ratio 0.63 ) and less frequently (4.8\%) reached a composite cardiovascular end-point (HR 0.50) compared with patients under standard control (<140 mmHg; $17 \%$ and $9.4 \%$, respectively). ${ }^{123}$

No evidence supports a preference for RAAS agents over other anti-hypertensive drugs among patients with CKD who present with hypertensive nephrosclerosis without proteinuria. The Antihypertensive and Lipid-Lowering Treatment to Prevent Heart Attack Trial (ALLHAT) did not find differences in the risk of exacerbated GFR or ESRD between patients given lisinopril, amlodipine, or chlorthalidone, ${ }^{125}$ even for the subgroup of patients with estimated GFRs $<60 \mathrm{~mL} / \mathrm{min}$. Although proteinuria was not directly measured in these patients, it was not expected to be elevated. ${ }^{126}$

\section{Multidrug Remission CKD Clinic Protocols}

Small annual differences in the rates of GFR decline can result in large differences regarding ESRD onset time. ${ }^{127}$ The goal of the RAAS-based individually tailored multidrug anti-proteinuric and antihypertensive treatments used over the last 15 years is to reduce proteinuria and the annual decline in eGFR. ${ }^{128}$ These protocols ${ }^{129}$ employ a combination therapy of ACE inhibitors and ARBs shown to reduce protein, kidney, and cardiovascular events more effectively than ACE inhibitors or ARB monotherapy. ${ }^{127,129,130}$ When proteinuria is minimal, a dual RAAS inhibitor is no more effective than a monotherapy (e.g. the ONTARGET Trial).79 The recent closure of the ALTITUDE and VA NEPHRON-D trials has placed the use of combination RAAS therapies on hold. ${ }^{80,81}$ A modified therapeutic strategy featuring a combination of lower-than-recommended doses of ACE inhibitors and ARB might block the RAAS system without excessive blood pressure reduction; moreover, the side effects of hyperkalemia and reduced kidney function are presently being investigated. ${ }^{130}$ The ongoing VALID trial, Preventing ESRD in Overt Nephropathy of Type 2 Diabetes Trial, is testing whether halved dosages of ACE inhibitor and ARB administered together compared with full doses of each agent alone result in a larger reduction in proteinuria and a delay in ESRD among approximately 100 individuals with type 2 diabetes over 3 years (ClinicalTrials.gov.NCTo0494715). The trial will be completed in February 2016.

\section{Updating the "Trade-off" Hypothesis}

\section{Hyperparathyroidism}

The progression of CKD and cardiovascular mortality have been directly correlated with changes in the levels of phosphate, calcium, PTH, vitamin D, and fibroblast growth factor 23 (FGF23). ${ }^{131}$ Laboratory studies in rats have demonstrated that PTH decreases glomerular filtration by decreasing the $K_{f}$ on the renal podocyte. ${ }^{132}$ The suppression of PTH via parathyroidectomy, calcimimetics (calcium-sensing receptor agonists), or dietary phosphate restriction attenuated the increase in serum creatinine in a rat remnant kidney model. ${ }^{133}$ Patients with CKD and secondary hyperparathyroidism have an increased mortality risk ${ }^{134}$ and a significantly shorter renal survival than those with CKD alone. ${ }^{135}$ Parathyroidectomy effectively reduces cardiovascular events and mortality in patients receiving hemodialysis with secondary hyperparathyroidism. ${ }^{136}$

\section{Phosphate}

The effect of phosphate on CKD progression might be directly mediated by changes in renal perfusion, calcifications, and intracellular calcium-phosphate concentrations, or through its indirect effects on PTH or calcium levels. ${ }^{137,138}$ The Irbesartan Diabetic Nephropathy Trial found that the risk of doubling serum creatinine levels, ESRD, or death ${ }^{139}$ was higher by a factor of 1.8 in hyperphosphatemic diabetics. ${ }^{139}$ The AASK analysis of African-American patients with hypertensive nephrosclerosis noted 
that phosphorus was directly associated with a renal composite consisting of $50 \%, 25 \mathrm{~mL} / \mathrm{min}$ GFR decline, or ESRD. ${ }^{140}$ Additional studies have shown that increasing serum phosphate concentrations are correlated with progressive renal failure ${ }^{141-144}$ and that phosphate restriction ${ }^{145,146}$ and phosphate binders stabilize renal function. ${ }^{147,148}$ An analysis of the medical files of 40,538 outpatients receiving hemodialysis registered in the Patient Profile System of Fresenius Medical Care found that high phosphorus was correlated with increased relative risks of death $(1.07,1.25,1.43,1.67$, and 2.02 for serum phosphorus levels of $5-6,6-7,7-8,8-9$, and $>9 \mathrm{mg} / \mathrm{dL}$, respectively). Higher adjusted calcium levels as well as moderate and severe hyperparathyroidism (PTH levels $\geq 600 \mathrm{pg} / \mathrm{mL}$ ) were also associated with increased rates of death. ${ }^{149}$ High phosphate is also associated with increased mortality in patients with CKD. ${ }^{141,149,150}$ Serum phosphate levels within the normal range are associated with coronary artery calcification as determined by CT scanning in patients with stage 3 and 4 CKD with or without diabetes mellitus. ${ }^{151}$ The graded ${ }^{152,153}$ associations between serum phosphate levels of $>3.5$ $\mathrm{mg} / \mathrm{dL}$ and coronary artery calcifications, ${ }^{156}$ cardiovascular disease, and mortality have also been extended to the general population. ${ }^{155^{-159}}$

In studying the population disparities in mineral metabolism,41,160 African-American patients with CKD demonstrate marked deficiencies in serum 25hydroxyvitamin D (25-OH vitamin D) and higher PTH levels than Caucasians. ${ }^{161-163}$ As these patients progress toward the need for dialysis, they show even more severe secondary hyperparathyroidism and 25-OH vitamin D deficiencies. ${ }^{164-166}$ This result was also shown by the multicenter Study to Evaluate Early Kidney Disease (SEEK) in 1,860 patients with early CKD, of whom $12 \%$ were African-American. African-Americans had significantly higher PTH, calcium, phosphorus, and bone-specific alkaline phosphatase levels. In addition, they had a 1.8-fold greater risk of elevated phosphate, a 2.7-fold greater risk of a $25-\mathrm{OH}$ vitamin D deficiency $<30 \mathrm{mg} / \mathrm{mL}$, and a 4.7-fold greater risk of a severe $25-\mathrm{OH}$ vitamin $\mathrm{D}$ deficiency. They also developed secondary hyperparathyroidism earlier in their CKD course at a GFR of $45^{-60} \mathrm{~mL} / \mathrm{min}$, whereas Caucasians generally developed hyperparathyroidism after their GFRs decreased to $<30 \mathrm{~mL} / \mathrm{min} .{ }^{167}$ Gutierrez et al. showed that both healthy African-Americans and those with CKD had a fractional excretion of inorganic phosphate that was approximately $30 \%$ lower than that for Caucasians $(P<0.001)$, and the fractional excretion of calcium in African-Americans was approximately $35 \%$ lower than in Caucasians. Both AfricanAmerican and Caucasian patients with CKD had eGFRs between 15 and $60 \mathrm{~mL} / \mathrm{min}$, and they had similar PTH and FGF23 levels. 168

Kestenbaum and colleagues described the results of a genome-wide association study (GWAS) that investigated common genetic variations associated with serum phosphorus concentrations in the general population. ${ }^{169}$ Seven loci were described, and one locus was found directly adjacent to SLC34A1, which encodes the kidney-specific type IIa sodiumphosphate co-transporter (NaPi2a). Another was located adjacent to the calcium-sensing receptor, and one was located close to the FGF23 receptor. The SLC34A1 was also one of the 13 loci identified by the CKDGen consortium, which performed a meta-analysis of the GWAS data in 67,093 individuals of European ancestry from 20 predominate population studies to identify new genetic susceptibility loci for reduced renal function. ${ }^{170}$ Although studied extensively in murine models where NaPi2a has been shown to serve as the central mediator of renal phosphate reabsorption, ${ }^{171,172}$ the role that this transporter plays in humans had been controversial until recently. Magen and associates recently described two siblings with autosomal recessive Fanconi's syndrome and hypophosphatemic rickets who featured a 21-base-pair in-frame duplication on SLC34A1. Functional studies have shown a complete loss of function of the mutant co-transporter, its failure to reach the plasma membrane, and an impairment of renal phosphate reabsorption. This study provided the first evidence in humans of the critical role that NaPi2a plays in human renal phosphate handling. ${ }^{173}$ Subsequently, novel loss-offunction mutations in SLC34A1 were identified in members of families with idiopathic infantile hypercalcemia (IIH) not attributed to abnormalities in inactivation of vitamin D processsing, many with nephrocalcinosis. ${ }^{174,175}$

A gain-of-function mechanism might explain the hyperphosphatemia in patients with $\mathrm{CKD}$, especially in light of its recent identification as a prominent CKD locus. ${ }^{176}$ People who tend toward lower fractional excretions of phosphate might exhibit increased levels of NaPi2a. ${ }^{167}$ The high and inducible levels of expression suggest that variant versions differ in folding and may trigger an "endoplasmic reticulum associated stress response (ERAD)."177 


\section{Vitamin D}

The diminished production of $1,25-\mathrm{OH}$ vitamin $\mathrm{D}$ in renal disease likely facilitates interstitial fibrosis by allowing fibroblasts to proliferate. ${ }^{139}$ Vitamin D has been shown to prevent glomerular disease in animal models, ${ }^{178,179}$ and its derivatives decrease urine albumin excretion as well as reducing serum creatinine and glomerulosclerosis in subtotally nephrectomized rats. ${ }^{180,181}$ In a retrospective analysis, patients with CKD who were treated with calcitriol showed a decreased rate of CKD progression. ${ }^{182}$ Increasing evidence has shown that the vitamin D analogue, paricalcitol, an inhibitor of the reninangiotensin system, ${ }^{183}$ reduces urinary albumin. Three recent studies showed that paricalcitol reduces proteinuria in patients with $\mathrm{CKD}$, including those presenting with diabetes. ${ }^{184-186}$ Paricalcitol reduced albuminuria and slowed the progression of kidney injury in laboratory animals. ${ }^{187,188} \mathrm{~A}$ recent double-blind, placebo-controlled study resulted in a $20 \%$ reduction in the urinary albumin-to-creatinine ratios $(P=0.053)$ and a $28 \%$ reduction in the 24hour urine albumin $(P=0.009)$ of patients receiving $2 \mu \mathrm{g}$ of paricalcitol for 24 weeks compared with those receiving a placebo. ${ }^{189}$

Decreased levels of $25-\mathrm{OH}$ and $1,25-\mathrm{OH}$ vitamin $\mathrm{D}$ are commonly observed in patients with $\mathrm{CKD}^{190}$ as well as associated with increased cardiovascular mortality. ${ }^{164,191}$ The treatment of CKD and ESRD populations using vitamin $\mathrm{D}$ compounds is associated with decreased mortality rates. ${ }^{192,193}$ However, a meta-analysis of 76 trials including 3,667 participants found that these compounds failed to reduce PTH levels or mortality rates consistently. ${ }^{194}$ Newer vitamin D compounds did decrease PTH levels (by $11 \mathrm{pmol} / \mathrm{L}$ ); intravenous therapy was more effective than oral therapy, but mortality rates were not affected. Additional observational studies by the same group confirmed the reduction of serum PTH and the increase in calcium and phosphorus following treatment with vitamin $\mathrm{D}$ compounds but failed to show increased survival rates. ${ }^{195,196}$ These studies sparked a call for randomized controlled trials to establish a causal association between vitamin D supplementation and decreased CKD mortality. ${ }^{197}$

Although the decreased production of $1,25-\mathrm{OH}$ vitamin $\mathrm{D}$ has traditionally been ascribed to decreased renal mass (which subsequently leads to elevated serum phosphate and the inhibition of reduced 25-OH D-1alpha-hydroxylase), these mechanisms fail to explain the decline in $1,25-\mathrm{OH}$ vitamin $\mathrm{D}$ in patients with early CKD who still have sufficient kidney mass and normal serum phosphate levels. ${ }^{198}$

\section{FGF23}

Fibroblast growth factor 23 (FGF23), which was initially characterized in a study of rare inherited disorders associated with phosphate metabolism, ${ }^{199}$ regulates phosphate homeostasis and explains the decreases in $1,25-\mathrm{OH}$ vitamin $\mathrm{D}$ in patients with early kidney disease. Its phosphaturic effect in the proximal tubules is accomplished through the downregulation of sodium-phosphate co-transporters, and it decreases $1,25-\mathrm{OH}$ vitamin $\mathrm{D}$ levels via the inhibition of 25-OHD-1-alphahydroxylase and the upregulation of the 25-OHD-24 hydroxylase pathway (Figure 4).198-203 Levels of FGF23 predict CKD progression from mild to moderate in patients of European ancestry, ${ }^{142}$ and they are among the strongest markers of CKD progression, with areas

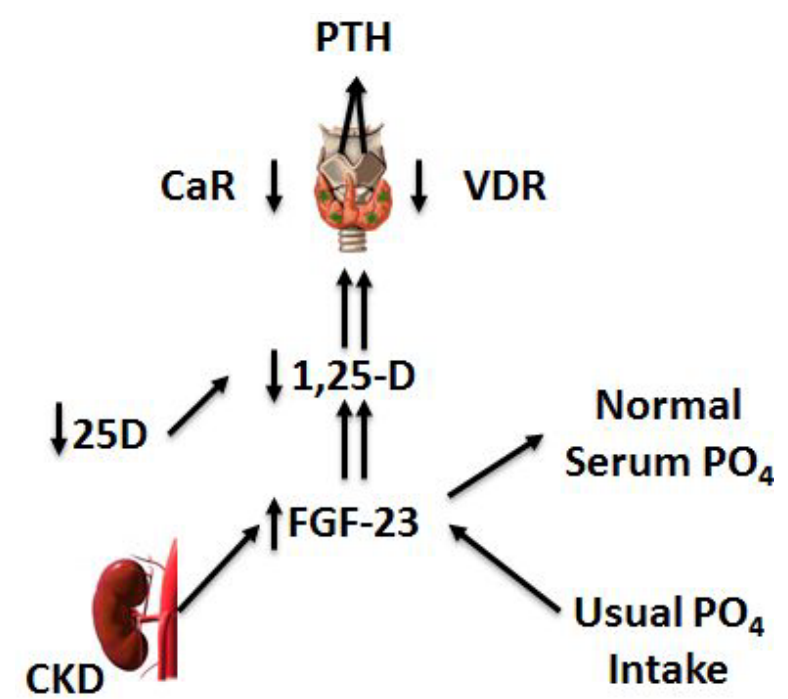

Figure 4. The Pathogenesis of Secondary Hyperparathyroidism (SHPT) in Chronic Kidney Disease (CKD).

The new perspective of SHPT in CKD emphasizes the degree of phosphate intake relative to the degree of kidney dysfunction and de-emphasizes the need for overt hypophosphatemia or hypocalcemia. Early FGF23 excess may be a key upstream event of increasing PTH in CKD. Note also the early 1,25-D deficiency.

Abbreviations: SHPT, secondary hyperparathyroidism; PTH, parathyroid hormone; CaR, calcium-sensing receptor; VDR, vitamin $D$ receptor.

Adapted from Figure 3 of Wahl and Wolf ${ }^{201}$ with the kind permission of the author and of Springer Science and Business Media (copyright 2012, Springer and Advances in Experimental Medicine and Biology). 
under the receiver-operating characteristic (ROC) curves of 0.84 for the C-terminal FGF23 and 0.81 for intact FGF23. ${ }^{131}$ Elevated FGF23 levels in patients with early CKD also predict early cardiovascular events such as myocardial infarction and stroke as well as the need for coronary artery or carotid artery intervention, peripheral arterial amputation or intervention, and death. ${ }^{204}$ Elevated FGF23 levels are associated with increased mortality, ${ }^{205,206}$ vascular calcifications, ${ }^{207}$ left ventricular hypertrophy and mass index, ${ }^{208}$ and bone metabolism abnormalities in patients with ESRD. ${ }^{209}$ Strategies to reduce FGF23 in early-stage CKD patients include dietary phosphate restriction, ${ }^{210}$ the use of phosphate binders, ${ }^{211}$ the administration of niacin, ${ }^{212}$ and the restriction of administration of vitamin Dtype drugs and favoring therapy with calcimimetics. ${ }^{213,214}$

The phosphate-regulating properties of FGF23 are mediated via FGFR1c, which requires alpha Klotho as a co-receptor. Its sites of action in the kidney are the subject of an active investigation and include the decreased expression of NaPi2a and NaPi2c. ${ }^{215}$ The recent demonstration of FGF23mediated signaling in the distal convoluted tubule at the site of the alpha Klotho co-receptor adjacent to the NaPi2a-expressing proximal tubular cells likely represents FGF23 bioactivity through nephronspecific events that have yet to be elucidated. ${ }^{216}$ Saito et al. hypothesized that the initial aberration in this signaling pathway is the inappropriate upregulation of NaPi2a receptors; 217 this theory is consistent with the association between the SLC34A1 locus and CKD described above.

An intriguing study recently found associations between FGF23 and body mass index (BMI), waist circumference, waist-to-hip ratio, serum lipids, and fat mass. In two cohorts of elderly European Caucasian participants, FGF23 was negatively associated with HDL and apolipoprotein A1 as well as positively associated with triglycerides. An increase of one standard deviation in the log-FGF23 levels was associated with a $7 \%-20 \%$ increase in BMI, waist circumference, and waist-to-hip ratio as well as a $7 \%-18 \%$ increase in trunk and total body fat mass as determined using whole-body dual X-ray absorptiometry. Levels of FGF23 were higher in participants with metabolic syndrome or at an increased risk of metabolic syndrome, ${ }^{218}$ indicating that FGF23 underlies cardiovascular risk via either phosphate or adverse lipid metabolism. The authors of that study cautioned against extending this associa- tion to African-American and Latino populations receiving dialysis; however, they emphasized that these populations have lower FGF23 levels ${ }^{205}$ and a dialysis survival advantage. ${ }^{164,219,220}$

Consistent experimental and human epidemiologic findings have suggested a need to test therapeutic approaches to lower phosphate levels in patients with CKD. ${ }^{221}$ Pilot studies of patients with stage 3 or 4 CKD suggest that phosphate binders, low phosphate diets, and vitamin B3 derivatives such as niacin and nicotinamide reduce phosphate absorption, serum phosphate, and FGF23. This novel therapeutic approach will be tested in the CKD Optimal Management with Binders and Nicotinamide (COMBINE) Study, with intermediate cardiovascular disease end-points to include left ventricular hypertrophy (LVH), vascular calcification, and CKD progression.

\section{Obesity and Metabolic Syndrome}

Obesity and associated metabolic syndrome, the results of Western dietary habits and sedentary lifestyles, exist at epidemic proportions in the US and are spreading worldwide. ${ }^{222}$ The continuous increase in obesity decreases life expectancy and general health. ${ }^{223}$ Obese participants are at greater risks for hypertension, insulin resistance and diabetes, hyperlipidemia, various cancers, and coronary vascular disease. ${ }^{224}$ Obesity and metabolic syndrome are also associated with pathologic renal changes and decreased renal function. ${ }^{224,225}$

Recently, the likely causes of the obesity epidemic were reviewed. ${ }^{226}$ Attempts to battle the problem have concentrated on decreasing fast food and trans fats intakes by providing nutritional information in stores and restaurants as well as reducing the consumption of soft drinks and high-fructose corn syrup. ${ }^{22}$ Numerous studies have associated increased trans fats intake with an increased risk of coronary disease. ${ }^{227-229}$ The intake of high-fructose corn syrup causes lipid abnormalities and hepatic insulin resistance. ${ }^{230}$ Epidemiologic studies show that the consumption of beverages containing a combination of sugars (including fructose) are associated with increases in body weight, metabolic syndrome, and cardiovascular disease. ${ }^{231}$ Similarly, the heightened use of artificial sweeteners is associated with obesity. ${ }^{232}$ Increasing evidence suggests that artificial sweeteners do not activate food reward pathways in the same manner as natural sweeteners, ${ }^{233}$ as demonstrated by the lack of the prolonged signal depression in the hypothalamus observed 
following glucose ingestion. Finally, sucrose ingestion, compared with saccharin ingestion, results in the greater activation of the higher gustatory areas such as the insula, orbitofrontal cortex, and the amygdala; this information might be useful for limiting energy intake. ${ }^{233-235}$

\section{Obesity}

The incidence of obesity, defined as a BMI of $\geq 30$ $\mathrm{kg} / \mathrm{m}^{2}$, has doubled since 1960. This condition affects one-third of the adult population in the US. The rise in overweight children from $6 \%$ to $19 \%$ over the past 25 years is even more alarming. ${ }^{236}$ Obesity is rapidly exceeding smoking as the leading cause of preventable death in the US. ${ }^{224}$ Eight studies have related excess body weight to the development of CKD and ESRD. ${ }^{237}$ An analysis of 320,252 members of the Kaiser Permanente Health System demonstrated that obesity is a risk factor for ESRD, with adjusted relative risks of $1.87,3.57,6.12$, and 7.07 for those with BMIs of 25-29.9, 30-34.9, 35-39.9, and $>40 \mathrm{~kg} / \mathrm{m}^{2}$, respectively. ${ }^{238}$ Although the World Health Organization continues to use BMI to define obesity, the waist-to-hip ratio has been shown to predict more accurately the myocardial infarct risk worldwide. ${ }^{239}$ The link between obesity (defined by waist-to-hip ratio) and CKD has been reported.240 Even lean individuals with a high waist-to-hip ratio were at risk for developing microalbuminuria and a reduced estimated GFR. ${ }^{241}$ Obesity-related focal segmental glomerulosclerosis has also been described. ${ }^{242}$ The pathogenesis of this disorder is likely related to hyperfiltration, with increases in kidney mass and a glomerular hypertrophy effect. Hyperfiltration and increased filtration fraction are surrogate markers for elevated glomerular capillary pressures, which eventually result in obesity-associated glomerulosclerosis. ${ }^{243}$ Obesity-associated focal segmental glomerulosclerosis is associated with a lower rate of nephrotic syndrome and a more indolent course than idiopathic focal segmental glomerulosclerosis. ${ }^{242}$

Paradoxically, a strong association between increased body mass index (BMI) and lower mortality has been described in numerous studies of patients with stage 5 CKD undergoing maintenance hemodialysis with the benefits of a larger size extending into morbid obesity $\left(\mathrm{BMI}>35 \mathrm{~kg} / \mathrm{m}^{2}\right) .24$ This has been extended by two studies of patients with CKD where low BMI predicted greater mortality, whereas increased BMI was associated with greater survival even after adjustment for known confounding variables. ${ }^{245,246}$ The reasons for this association have not been determined.

\section{Metabolic Syndrome}

Associations between metabolic syndrome and both $\mathrm{CKD}$ and microalbuminuria have also been found in numerous studies, and Peralta et al. recently reviewed these relationships. ${ }^{247}$ After examining the data of 6,217 adults in the National Health and Nutrition Examination Survey III (NHANES), 24.7\% of whom had metabolic syndrome, Chen et al. demonstrated graded relationships between the components of metabolic syndrome and the risks for CKD and microalbuminuria. ${ }^{248}$ Due to the crosssectional nature of the study, determination of the temporal relationship between metabolic syndrome and CKD was not possible. ${ }^{247}$ The Atherosclerosis Risk in Communities Study (ARIC) examined more than 15,000 individuals and found that $21 \%$ $(n=2,110)$ and $7 \%(n=691)$ developed metabolic syndrome and CKD, respectively, over a 9-year period; moreover, a similar graded relationship was found between the components of the syndrome and the risk for CKD. The odds ratio for the rate of CKD among participants with metabolic syndrome was 1.24 (95\% CI 1.01-1.51).

Similarly, experimental hyperlipidemia models have demonstrated associations among progressive kidney damage, atherosclerosis, focal segmental glomerulosclerosis, and tubule-interstitial disease. ${ }^{249}$ Interestingly, a recent investigation of 19,246 participants in the southern US documented an association between a high saturated fat intake and albuminuria; however, no relationship was found with regard to decreased GFR. ${ }^{25}$ Moreover, an increased fructose intake $(\geq 74 \mathrm{~g} /$ day $)$ was implicated in obesity, metabolic syndrome, uric acid elevations, and hypertension; furthermore, it was a risk factor for kidney disease. ${ }^{251}$ High-fructose diets in animals led to renal hypertrophy, tubular cell proliferation, and injury. In a remnant kidney model, rats fed diets high in fructose developed metabolic syndrome and kidney disease progression. ${ }^{252}$ In humans, 6week diets containing $25 \%$ fructose caused insulin resistance, visceral obesity, and abnormalities in serum lipids consistent with metabolic syndrome. ${ }^{253}$ The NHANES revealed an association between the ingestion of sugar-sweetened drinks and elevated uric acid levels; hypertension was also observed.253 Similarly, the Nurses' Health Study found that $\geq 2$ 
daily servings of artificially sweetened soda was independently associated with $a \geq 30 \%$ decline in estimated GFR over 11 years. ${ }^{254}$

A recent histopathologic study compared samples from 12 patients with metabolic syndrome undergoing nephrectomy for renal cancer with those from 12 controls. ${ }^{255}$ Samples from the patients with metabolic syndrome showed greater tubular atrophy, interstitial fibrosis, and arteriosclerosis as well as global and segmental glomerulosclerosis. These prominent interstitial changes led Saito et al. to postulate that the proximal tubular cell and, specifically, the multiligand megalin and cubilin receptors play a prominent role in the pathogenesis of this disorder. ${ }^{217}$

Welsh et al. recently engineered two mouse models lacking glomerular podocyte insulin receptors. ${ }^{25}$ Within 5 weeks, the animals began to show albuminuria and a shortening of the foot processes under electron microscopy. At 8 weeks, albuminuria, increased creatinine levels, the foci of segmental sclerosis, a thickening of the basement membranes, histologic evidence of apoptosis, and histopathologic features of diabetic nephropathy were observed, demonstrating the importance of podocyte insulin sensitivity in kidney function. ${ }^{257}$

According to the KDIGO guidelines, many patients with CKD should be treated with statins to prevent cardiovascular disease. 53

\section{Diabetes Mellitus}

The importance of tight glycemic control to prevent kidney disease-related outcomes was recently demonstrated by the Diabetes Control and Complications Trial/Epidemiology of Diabetes Interventions and Complications Study (DCCT/ EDIC). ${ }^{25}$ The DCCT examined 1,441 participants with type 1 diabetes mellitus (1982-1993) assigned to intensive (median $\mathrm{HgA1C}$ 7.2\%) versus conventional (9.1\%) treatment for 6.5 years. Subsequently, participants were followed for $>18$ years in the observational EDIC. The intensive treatment used three or more daily insulin injections or insulin pump therapy guided by self-monitored glucose. During the DCCT, the intensive treatment reduced the rate of microalbuminuria (albumin excretion rate (AER) $>40$ $\mathrm{mg} / 24 \mathrm{~h}$ ) by $39 \%$ and that of macroalbuminuria (AER $>300 \mathrm{mg} / 24 \mathrm{~h}$ ) by $54 \%(24 \%-74 \%)$. During EDIC years 1-8, participants previously assigned to the DCCT intensive treatment experienced lower rates of microalbuminuria and macroalbuminuria, with risk reductions of $59 \%(30 \%-73 \%)$ and $84 \%$ $(67 \%-92 \%)$, respectively. The beneficial effects of intensive therapy became evident at the end of the follow-up assessment, with reduced risks of impaired GFR $(<60 \mathrm{~mL} / \mathrm{min})$ and hypertension of $50 \%(18 \%-69 \%)$ and $20 \%(6 \%-21 \%)$, respectively. The risk for retinopathy and neuropathy was also reduced, but not the risk for cardiovascular events.

With regard to type 2 diabetes, the kidney disease outcomes of the United Kingdom Prospective Diabetes Study (UKPDS), ${ }^{259}$ Kumamoto, ${ }^{260}$ Action in Diabetes and Vascular Disease Trial (ADVANCE), ${ }^{261}$ and Action to Control Cardiovascular Risk in Diabetes (ACCORD) ${ }^{262}$ trials are consistent with those of the DCCT for patients with type 1 diabetes. ${ }^{258}$ These analyses account for the relative differences in hemoglobin $\mathrm{A} 1 \mathrm{C}$ achieved between treatment groups and the differences in study duration. A metaanalysis of type 2 diabetics ${ }^{263}$ featured 28 trials that included 34,912 participants with type 2 diabetes who were randomly assigned to an intensive glycemic control group $(n=18,717)$ or a conventional glycemic control group $(n=16,195)$. Targeting intensive glycemic control reduced the risk of microvascular complications (i.e. nephropathy and retinopathy) but increased the risks for hypoglycemia and serious adverse events. Tight glucose control confers long-term benefits regarding the prevention of progressive diabetic kidney disease.

Many individuals are not candidates for intensive glucose control in view of frequent episodes of hypoglycemia, impaired cognitive status, multiple co-morbidities, and shortened life expectancies. Clinical guidelines have therefore recommended hemoglobin $\mathrm{A} 1 \mathrm{C}$ targets as follows: specifically "individualized" care with $\mathrm{A} 1 \mathrm{C} \sim 6.5 \%$ for healthy, young patients; $<7 \%$ in older individuals or those with co-morbid conditions, and $<8 \%$ in older individuals with just a few years of life expectancy. ${ }^{264,265}$

\section{Other Risk Factors}

Studies recently have identified uric acid,,266-268 acidosis, ${ }^{269-272}$ and acute kidney injury273,274 as potentially modifiable risk factors for CKD.

\section{CONCLUSIONS}

By nature, nephrologists are intelligent, creative, and competitive. As such, we are envious of the extraordinary success of our cardiology colleagues in the treatment of cardiovascular disease, and we wish to mirror their success. The aforementioned discus- 
sion of CKD risk factors makes the conceptual historical point of the importance of risk factor modification. Using this approach, in collaboration with our fellow clinicians, we can prolong the lives of individuals with kidney disease, target cardiovascular prevention, and decrease the number of patients referred for renal replacement therapy and kidney transplantation. Research presently underway will target multiple novel pathways and identify multidrug approaches to accomplish these goals. $97,98,275$

The plateauing incidence of ESRD in the US over recent years indicates that these efforts have already shown success. The latest United States Renal Data System (USRDS) Annual Data Report from 2014 showed that the rate of ESRD has fallen from 368 cases per 1 million people in 2009 to 359 cases per 1 million people in 2012. The actual incidence has also fallen from 115,114 in 2009 to 114,813 in $2012 .{ }^{16}$ This marks the first time that the USRDS has reported a decrease in the number of new patients with ESRD since it began reporting in 1980. A decrease in incidence counts has also been reported for a number of other countries including Israel, ${ }^{16}$ perhaps reflecting attention to risk factor treatment.

\section{REFERENCES}

1. Cooney MT, Dudina A, D’Agostino R, Graham IM. Cardiovascular risk-estimation systems in primary prevention: do they differ? Do they make a difference? Can we see the future? Circulation 2010;122: 300-10. Full Text

2. National Institutes of Health, National Heart, Lung, and Blood Institute. Fact Book Fiscal Year 2012; Chapter 4. Disease Statistics. Bethesda, MD; National Institutes of Health, National Heart, Lung, and Blood Institute; 2013:33-52. Available at: http://1.usa.gov/ 1MPNZEf. Accessed June 23, 2015 .

3. Braunwald E. Shattuck lecture--cardiovascular medicine at the turn of the millennium: triumphs, concerns, and opportunities. N Engl J Med 1997;337: 1360-9. Full Text

4. Kannel WB, Dawber TR, Kagan A, Revotskie N, Stokes J 3rd. Factors of risk in the development of coronary heart disease--six year follow-up experience. The Framingham Study. Ann Intern Med 1961;55:33-50. Full Text

5. Wilson PW, D'Agostino RB, Levy D, Belanger AM, Silbershatz H, Kannel WB. Prediction of coronary heart disease using risk factor categories. Circulation 1998;97:1837-47. Full Text
6. Wilson PW, Castelli WP, Kannel WB. Coronary risk prediction in adults (the Framingham Heart Study). Am J Cardiol 1987;59:91G-4G. Full Text

7. Ford ES, Ajani UA, Croft JB, et al. Explaining the decrease in U.S. deaths from coronary disease, 19802000. N Engl J Med 2007;356:2388-98. Full Text

8. Batsis JA, Lopez-Jimenez F. Cardiovascular risk assessment--from individual risk prediction to estimation of global risk and change in risk in the population. BMC Med 2010;8:29. Full Text

9. Humphries SE, Drenos F, Ken-Dror G, Talmud PJ. Coronary heart disease risk prediction in the era of genome-wide association studies: current status and what the future holds. Circulation 2010;121:223548. Full Text

10. Peitzman SJ. Chronic dialysis and dialysis doctors in the United States: a nephrologist-historian's perspective. Semin Dial 2001;14:200-8. Full Text

11. Peitzman SJ. Nephrology in the United States from Osler to the artificial kidney. Ann Intern Med 1986; 105:937-46. Full Text

12. Murray JE, Merrill JP, Harrison JH, Wilson RE, Dammin GJ. Prolonged survival of human-kidney homografts by immunosuppressive drug therapy. $\mathrm{N}$ Engl J Med 1963;268:1315-23. Full Text

13. Alexander S. Medical miracle and a moral burden of a small committee: they decide who lives, who dies. Life 1962:102-25.

14. Levinsky NG. Management of chronic renal failure. N Engl J Med 1964;271:460-3. Full Text

15. Ympa YP, Sakr Y, Reinhart K, Vincent JL. Has mortality from acute renal failure decreased? A systematic review of the literature. Am J Med 2005;118:827-32. Full Text

16. United States Renal Data System, 2014 Annual Data Report: Epidemiology of Kidney Disease in the United States. Bethesda, MD: National Institutes of Health, National Institute of Diabetes and Digestive and Kidney Diseases; 2014. Available at: http://www.usrds.org/adr.aspx. Accessed May 19, 2015 .

17. Bricker NS. On the pathogenesis of the uremic state. An exposition of the "trade-off hypothesis". N Engl J Med 1972;286:1093-9. Full Text

18. Bricker NS, Morrin PA, Kime SW Jr. The pathologic physiology of chronic Bright's disease. An exposition of the "intact nephron hypothesis". Am J Med 1960;28:77-98. Full Text

19. Cain CD, Schroeder FC, Shankel SW, Mitchnick M, Schmertzler M, Bricker NS. Identification of xanthurenic acid 8-O-beta-D-glucoside and xanthurenic 
acid 8-O-sulfate as human natriuretic hormones. Proc Natl Acad Sci U S A 2007;104:17873-8. Full $\underline{\text { Text }}$

20. Hostetter TH, Olson JL, Rennke HG, Venkatachalam MA, Brenner BM. Hyperfiltration in remnant nephrons: a potentially adverse response to renal ablation. Am J Physiol 1981;241:F85-93.

21. Matsusaka T, Hymes J, Ichikawa I. Angiotensin in progressive renal diseases: theory and practice. J Am Soc Nephrol 1996;7:2025-43.

22. Zatz R, Dunn BR, Meyer TW, Anderson S, Rennke HG, Brenner BM. Prevention of diabetic glomerulopathy by pharmacological amelioration of glomerular capillary hypertension. J Clin Invest 1986;77: 1925-30. Full Text

23. Fogo A, Ichikawa I. Evidence for a pathogenic linkage between glomerular hypertrophy and sclerosis. Am J Kidney Dis 1991;17:666-9. Full Text

24. Yoshida Y, Fogo A, Ichikawa I. Glomerular hemodynamic changes vs. hypertrophy in experimental glomerular sclerosis. Kidney Int 1989;35:654-60. Full Text

25. Levey AS, de Jong PE, Coresh J, et al. The definition, classification, and prognosis of chronic kidney disease: a KDIGO Controversies Conference report. Kidney Int 2011;80:17-28. Full Text

26. Levey AS, Astor BC, Stevens LA, Coresh J. Chronic kidney disease, diabetes, and hypertension: what's in a name? Kidney Int 2010;78:19-22. Full Text

27. Lindner A, Charra B, Sherrard DJ, Scribner BH. Accelerated atherosclerosis in prolonged maintenance hemodialysis. N Engl J Med 1974;290:697-701. Full Text

28. Mogensen CE. Microalbuminuria predicts clinical proteinuria and early mortality in maturity-onset diabetes. N Engl J Med 1984;310:356-60. Full Text

29. Bigazzi R, Bianchi S, Baldari D, Campese VM. Microalbuminuria predicts cardiovascular events and renal insufficiency in patients with essential hypertension. J Hypertens 1998;16:1325-33. Full $\underline{\text { Text }}$

30. Perkovic V, Verdon C, Ninomiya T, et al. The relationship between proteinuria and coronary risk: a systematic review and meta-analysis. PLoS Med 2008;5:e207. Full Text

31. Ninomiya T, Perkovic V, Verdon C, et al. Proteinuria and stroke: a meta-analysis of cohort studies. Am J Kidney Dis 2009;53:417-25. Full Text

32. Lewis EJ, Hunsicker LG, Clarke WR, et al. Renoprotective effect of the angiotensin-receptor antagonist irbesartan in patients with nephropathy due to type
2 diabetes. N Engl J Med 2001;345:851-60. Full Text

33. Brenner BM, Cooper ME, de Zeeuw D, et al. Effects of losartan on renal and cardiovascular outcomes in patients with type 2 diabetes and nephropathy. $\mathrm{N}$ Engl J Med 2001;345:861-9. Full Text

34. de Zeeuw D, Remuzzi G, Parving HH, et al. Proteinuria, a target for renoprotection in patients with type 2 diabetic nephropathy: lessons from RENAAL. Kidney Int 2004;65:2309-20. Full Text

35. Yusuf S, Sleight P, Pogue J, Bosch J, Davies R, Dagenais G. Effects of an angiotensin-convertingenzyme inhibitor, ramipril, on cardiovascular events in high-risk patients. The Heart Outcomes Prevention Evaluation Study Investigators. N Engl J Med 2000;342:145-53. Full Text

36. Ibsen $\mathrm{H}$, Olsen $\mathrm{MH}$, Wachtell $\mathrm{K}$, et al. Reduction in albuminuria translates to reduction in cardiovascular events in hypertensive patients: losartan intervention for endpoint reduction in hypertension study. Hypertension 2005;45:198-202. Full Text

37. Chamnan P, Simmons RK, Khaw KT, Wareham NJ, Griffin SJ. Estimating the population impact of screening strategies for identifying and treating people at high risk of cardiovascular disease: modelling study. BMJ 2010;340:c1693.

38. Marshall T. Targeted case finding for cardiovascular prevention. BMJ 2010;340:c1376. Full Text

39. Vischer UM, Safar ME, Safar H, et al. Cardiometabolic determinants of mortality in a geriatric population: is there a "reverse metabolic syndrome"? Diabetes Metab 2009;35:108-14. Full Text

40. Hallan SI. Kidney function for the non-nephrologist: an emerging tool for predicting mortality risk. Kidney Int 2010;79:8-10. Full Text

41. Weiner DE, Tighiouart H, Amin MG, et al. Chronic kidney disease as a risk factor for cardiovascular disease and all-cause mortality: a pooled analysis of community-based studies. J Am Soc Nephrol 2004; 15:1307-15. Full Text

42. Henry RM, Kostense PJ, Bos G, et al. Mild renal insufficiency is associated with increased cardiovascular mortality: The Hoorn Study. Kidney Int 2002;62:1402-7. Full Text

43. Go AS, Chertow GM, Fan D, McCulloch CE, Hsu CY. Chronic kidney disease and the risks of death, cardiovascular events, and hospitalization. N Engl J Med 2004;351:1296-305. Full Text

44. Matsushita K, van der Velde M, Astor BC, et al. Association of estimated glomerular filtration rate and albuminuria with all-cause and cardiovascular mortality in general population cohorts: a collabora- 
tive meta-analysis. Lancet 2010;375:2073-81. Full Text

45. Hemmelgarn BR, Manns BJ, Lloyd A, et al. Relation between kidney function, proteinuria, and adverse outcomes. JAMA 2010;303:423-9. Full Text

46. DeFilippis AP, Kramer HJ, Katz R, et al. Association between coronary artery calcification progression and microalbuminuria: the MESA study. JACC Cardiovasc Imaging 2010;3:595-604. Full Text

47. Hallan S, Astor B, Romundstad S, Aasarod K, Kvenild K, Coresh J. Association of kidney function and albuminuria with cardiovascular mortality in older vs younger individuals: The HUNT II Study. Arch Intern Med 2007;167:2490-6. Full Text

48. Foley RN, Wang C, Snyder JJ, Rule AD, Collins AJ. Kidney function and risk triage in adults: threshold values and hierarchical importance. Kidney Int 2010;79:99-111. Full Text

49. Soveri I, Arnlov J, Berglund L, Lind L, Fellstrom B, Sundstrom J. Kidney function and discrimination of cardiovascular risk in middle-aged men. J Intern Med 2009;266:406-13. Full Text

50. Van Biesen W, De Bacquer D, Verbeke F, Delanghe J, Lameire N, Vanholder R. The glomerular filtration rate in an apparently healthy population and its relation with cardiovascular mortality during 10 years. Eur Heart J 2007;28:478-83. Full Text

51. Upadhyay A, Earley A, Lamont JL, Haynes S, Wanner C, Balk EM. Lipid-lowering therapy in persons with chronic kidney disease: a systematic review and meta-analysis. Ann Intern Med 2012;157:251-62. Full Text

52. Palmer SC, Craig JC, Navaneethan SD, Tonelli M, Pellegrini F, Strippoli GF. Benefits and harms of statin therapy for persons with chronic kidney disease: a systematic review and meta-analysis. Ann Intern Med 2012;157:263-75. Full Text

53. Wanner C, Tonelli M; Kidney Disease: Improving Global Outcomes Lipid Guideline Development Work Group Members. KDIGO Clinical Practice Guideline for Lipid Management in Chronic Kidney Disease. Kidney Int 2014;85:1303-9. Full Text

54. Klahr S, Schreiner G, Ichikawa I. The progression of renal disease. N Engl J Med 1988;318:1657-66. $\underline{\text { Full }}$ $\underline{\text { Text }}$

55. Peterson JC, Adler S, Burkart JM, et al. Blood pressure control, proteinuria, and the progression of renal disease. The Modification of Diet in Renal Disease Study. Ann Intern Med 1995;123:754-62. Full Text

56. Sarnak MJ, Greene T, Wang X, et al. The effect of a lower target blood pressure on the progression of kidney disease: long-term follow-up of the modification of diet in renal disease study. Ann Intern Med 2005;142:342-51. Full Text

57. Ruggenenti P, Perna A, Gherardi G, Benini R, Remuzzi G. Chronic proteinuric nephropathies: outcomes and response to treatment in a prospective cohort of 352 patients with different patterns of renal injury. Am J Kidney Dis 2000;35:1155-65. Full Text

58. Schrier RW, Estacio RO, Esler A, Mehler P. Effects of aggressive blood pressure control in normotensive type 2 diabetic patients on albuminuria, retinopathy and strokes. Kidney Int 2002;61:1086-97. Full Text

59. Wright JT Jr, Bakris G, Greene T, et al. Effect of blood pressure lowering and antihypertensive drug class on progression of hypertensive kidney disease: results from the AASK trial. JAMA 2002;288:242131. Full Text

6o. Remuzzi G, Ruggenenti P, Perico N. Chronic renal diseases: renoprotective benefits of renin-angiotensin system inhibition. Ann Intern Med 2002;136: 604-15. Full Text

61. Jafar TH, Stark PC, Schmid CH, et al. Progression of chronic kidney disease: the role of blood pressure control, proteinuria, and angiotensin-converting enzyme inhibition: a patient-level meta-analysis. Ann Intern Med 2003;139:244-52. Full Text

62. Jafar TH, Schmid CH, Landa M, et al. Angiotensinconverting enzyme inhibitors and progression of nondiabetic renal disease. A meta-analysis of patient-level data. Ann Intern Med 2001;135:73-87. $\underline{\text { Full Text }}$

63. Lewis EJ, Hunsicker LG, Bain RP, Rohde RD. The effect of angiotensin-converting-enzyme inhibition on diabetic nephropathy. The Collaborative Study Group. N Engl J Med 1993;329:1456-62. Full Text

64. Hoy WE, Wang Z, VanBuynder P, Baker PR, Mathews JD. The natural history of renal disease in Australian Aborigines. Part 1. Changes in albuminuria and glomerular filtration rate over time. Kidney Int 2001;60:243-8. Full Text

65. Ruilope LM, Campo C, Rodriguez-Artalejo F, Lahera V, Garcia-Robles R, Rodicio JL. Blood pressure and renal function: therapeutic implications. $\mathrm{J}$ Hypertens 1996;14:1259-63. Full Text

66. Iseki K, Ikemiya Y, Iseki C, Takishita S. Proteinuria and the risk of developing end-stage renal disease. Kidney Int 2003;63:1468-74. Full Text

67. Ruggenenti P, Fassi A, Ilieva AP, et al. Preventing microalbuminuria in type 2 diabetes. $\mathrm{N}$ Engl $\mathrm{J}$ Med 2004;351:1941-51. Full Text

68. Ravid M, Brosh D, Levi Z, Bar-Dayan Y, Ravid D, Rachmani R. Use of enalapril to attenuate decline in 
renal function in normotensive, normoalbuminuric patients with type 2 diabetes mellitus. A randomized, controlled trial. Ann Intern Med 1998;128: 982-8. Full Text

69. Slagman MC, Navis G, Laverman GD. Dual blockade of the renin-angiotensin-aldosterone system in cardiac and renal disease. Curr Opin Nephrol Hypertens 2010;19:140-52. Full Text

70. Nakao N, Yoshimura A, Morita H, Takada M, Kayano T, Ideura T. Combination treatment of angiotensin-II receptor blocker and angiotensinconverting-enzyme inhibitor in non-diabetic renal disease (COOPERATE): a randomised controlled trial. Lancet 2003;361:117-24. Full Text

71. Viberti G, Wheeldon NM. Microalbuminuria reduction with valsartan in patients with type 2 diabetes mellitus: a blood pressure-independent effect. Circulation 2002;106:672-8. Full Text

72. Parving $\mathrm{HH}$, Lehnert $\mathrm{H}$, Brochner-Mortensen J, Gomis R, Andersen S, Arner P. The effect of irbesar$\tan$ on the development of diabetic nephropathy in patients with type 2 diabetes. N Engl J Med 2001; 345:870-8. Full Text

73. Barnett AH, Bain SC, Bouter P, et al. Angiotensinreceptor blockade versus converting-enzyme inhibition in type 2 diabetes and nephropathy. $\mathrm{N}$ Engl $\mathrm{J}$ Med 2004;351:1952-61. Full Text

74. Ruggenenti P, Perna A, Remuzzi G. Retarding progression of chronic renal disease: the neglected issue of residual proteinuria. Kidney Int 2003;63:225461. Full Text

75. Eijkelkamp WB, Zhang Z, Remuzzi G, et al. Albuminuria is a target for renoprotective therapy independent from blood pressure in patients with type 2 diabetic nephropathy: post hoc analysis from the Reduction of Endpoints in NIDDM with the Angiotensin II Antagonist Losartan (RENAAL) trial. J Am Soc Nephrol 2007;18:1540-6. Full Text

76. Ruggenenti P, Cravedi P, Remuzzi G. The RAAS in the pathogenesis and treatment of diabetic nephropathy. Nat Rev Nephrol 2010;6:319-30. Full Text

77. Teo K, Yusuf S, Sleight P, et al. Rationale, design, and baseline characteristics of 2 large, simple, randomized trials evaluating telmisartan, ramipril, and their combination in high-risk patients: the Ongoing Telmisartan Alone and in Combination with Ramipril Global Endpoint Trial/Telmisartan Randomized Assessment Study in ACE Intolerant Subjects with Cardiovascular Disease (ONTARGET/TRANSCEND) trials. Am Heart J 2004;148:52-61. Full Text

78. Weber MA. Hypertension treatment and implications of recent cardiovascular outcome trials. J Hypertens Suppl 2006;24:S37-44. Full Text
79. Ontarget Investigators; Yusuf S, Teo KK, et al. Telmisartan, ramipril, or both in patients at high risk for vascular events. N Engl J Med 2008;358: 1547-59. Full Text

8o. Fried LF, Emanuele N, Zhang JH, et al. Combined angiotensin inhibition for the treatment of diabetic nephropathy. N Engl J Med 2013;369:1892-903. Full Text

81. Parving HH, Brenner BM, McMurray JJ, et al. Cardiorenal end points in a trial of aliskiren for type 2 diabetes. N Engl J Med 2012;367:2204-13. Full Text

82. Persson F, Rossing P. Sequential RAAS blockade: is it worth the risk? Adv Chronic Kidney Dis 2014;21: 159-65. Full Text

83. Hou FF, Xie D, Zhang X, et al. Renoprotection of Optimal Antiproteinuric Doses (ROAD) Study: a randomized controlled study of benazepril and losar tan in chronic renal insufficiency. J Am Soc Nephrol 2007;18:1889-98. Full Text

84. Rossing K, Schjoedt KJ, Jensen BR, Boomsma F, Parving HH. Enhanced renoprotective effects of ultrahigh doses of irbesartan in patients with type 2 diabetes and microalbuminuria. Kidney Int 2005;68:1190-8. Full Text

85. Weir MR, Hollenberg NK, Zappe DH, et al. Antihypertensive effects of double the maximum dose of valsartan in African-American patients with type 2 diabetes mellitus and albuminuria. J Hypertens 2010;28:186-93. Full Text

86. Schmieder RE, Klingbeil AU, Fleischmann EH, Veelken R, Delles C. Additional antiproteinuric effect of ultrahigh dose candesartan: a double-blind, randomized, prospective study. J Am Soc Nephrol 2005;16:3038-45. Full Text

87. Burgess E, Muirhead N, Rene de Cotret P, et al. Supramaximal dose of candesartan in proteinuric renal disease. J Am Soc Nephrol 2009;20:893-900. Full Text

88. Persson F, Rossing P, Reinhard H, et al. Optimal antiproteinuric dose of aliskiren in type 2 diabetes mellitus: a randomised crossover trial. Diabetologia 2010;53:1576-80. Full Text

89. Schjoedt KJ, Astrup AS, Persson F, et al. Optimal dose of lisinopril for renoprotection in type 1 diabetic patients with diabetic nephropathy: a randomised crossover trial. Diabetologia 2009;52: 46-9. Full Text

90. Andersen S, Rossing P, Juhl TR, Deinum J, Parving $\mathrm{HH}$. Optimal dose of losartan for renoprotection in diabetic nephropathy. Nephrol Dial Transplant 2002;17:1413-18. Full Text

91. Krikken JA, Laverman GD, Navis G. Benefits of dietary sodium restriction in the management of 
chronic kidney disease. Curr Opin Nephrol Hypertens 2009;18:531-8. Full Text

92. Buter H, Hemmelder MH, Navis G, de Jong PE, de Zeeuw D. The blunting of the antiproteinuric efficacy of ACE inhibition by high sodium intake can be restored by hydrochlorothiazide. Nephrol Dial Transplant 1998;13:1682-5. Full Text

93. Esnault VL, Ekhlas A, Delcroix C, Moutel MG, Nguyen JM. Diuretic and enhanced sodium restriction results in improved antiproteinuric response to RAS blocking agents. J Am Soc Nephrol 2005;16: 474-81. Full Text

94. Navis G, de Jong PE, Donker AJ, van der Hem GK, de Zeeuw D. Moderate sodium restriction in hypertensive subjects: renal effects of ACE-inhibition. Kidney Int 1987;31:815-19. Full Text

95. Houlihan CA, Allen TJ, Baxter AL, et al. A lowsodium diet potentiates the effects of losartan in type 2 diabetes. Diabetes Care 2002;25:663-71. Full Text

96. Vogt L, Waanders F, Boomsma F, de Zeeuw D, Navis G. Effects of dietary sodium and hydrochlorothiazide on the antiproteinuric efficacy of losartan. J Am Soc Nephrol 2008;19:999-1007. Full Text

97. Weir MR, Bakris GL, Bushinsky DA, et al. Patiromer in patients with kidney disease and hyperkalemia receiving RAAS inhibitors. N Engl J Med 2015;372: 211-21. Full Text

98. Packham DK, Rasmussen HS, Lavin PT, et al. Sodium zirconium cyclosilicate in hyperkalemia. N Engl J Med 2015;372:222-31. Full Text

99. Bakris GL, Williams M, Dworkin L, et al. Preserving renal function in adults with hypertension and diabetes: a consensus approach. National Kidney Foundation Hypertension and Diabetes Executive Committees Working Group. Am J Kidney Dis 2000;36:646-61. Full Text

100. Mangrum AJ, Bakris GL. Angiotensin-converting enzyme inhibitors and angiotensin receptor blockers in chronic renal disease: safety issues. Semin Nephrol 2004;24:168-75. Full Text

101. Xie D, Hou FF, Fu BL, Zhang X, Liang M. High level of proteinuria during treatment with renin-angiotensin inhibitors is a strong predictor of renal outcome in nondiabetic kidney disease. $J$ Clin Pharmacol 2011;51:1025-34. Full Text

102. Bakris GL, Weir MR, Secic M, Campbell B, WeisMcNulty A. Differential effects of calcium antagonist subclasses on markers of nephropathy progression. Kidney Int 2004;65:1991-2002. Full Text

103. Effect of enalapril on survival in patients with reduced left ventricular ejection fractions and congestive heart failure. The SOLVD Investigators. N Engl J Med 1991;325:293-302. Full Text

104. Jong P, Yusuf S, Rousseau MF, Ahn SA, Bangdiwala SI. Effect of enalapril on 12-year survival and life expectancy in patients with left ventricular systolic dysfunction: a follow-up study. Lancet 2003;361: 1843-8. Full Text

105. Dagenais GR, Pogue J, Fox K, Simoons ML, Yusuf S. Angiotensin-converting-enzyme inhibitors in stable vascular disease without left ventricular systolic dysfunction or heart failure: a combined analysis of three trials. Lancet 2006;368:581-8. Full Text

106. Effects of ramipril on cardiovascular and microvascular outcomes in people with diabetes mellitus: results of the HOPE study and MICRO-HOPE substudy. Heart Outcomes Prevention Evaluation Study Investigators. Lancet 2000;355:253-9. Full Text

107. Keane WF, Brenner BM, de Zeeuw D, et al. The risk of developing end-stage renal disease in patients with type 2 diabetes and nephropathy: the RENAAL study. Kidney Int 2003;63:1499-507. Full Text

108. Rachmani R, Levi Z, Lidar M, Slavachevski I, HalfOnn E, Ravid M. Considerations about the threshold value of microalbuminuria in patients with diabetes mellitus: lessons from an 8-year follow-up study of 599 patients. Diabetes Res Clin Pract 2000;49:18794. Full Text

109. Pereira M, Lunet N, Azevedo A, Barros H. Differences in prevalence, awareness, treatment and control of hypertension between developing and developed countries. J Hypertens 2009;27:963-75. Full Text

110. Kearney PM, Whelton M, Reynolds K, Muntner P, Whelton PK, He J. Global burden of hypertension: analysis of worldwide data. Lancet 2005;365:21723. Full Text

111. Abegunde DO, Mathers CD, Adam T, Ortegon M, Strong K. The burden and costs of chronic diseases in low-income and middle-income countries. Lancet 2007;370:1929-38. Full Text

112. Perry HM Jr, Miller JP, Fornoff JR, et al. Early predictors of 15 -year end-stage renal disease in hypertensive patients. Hypertension 1995;25:587-94. Full $\underline{\text { Text }}$

113. Klag MJ, Whelton PK, Randall BL, et al. Blood pressure and end-stage renal disease in men. N Engl J Med 1996;334:13-18. Full Text

114. Walker WG, Neaton JD, Cutler JA, Neuwirth R, Cohen JD. Renal function change in hypertensive members of the Multiple Risk Factor Intervention Trial. Racial and treatment effects. The MRFIT 
Research Group. JAMA 1992;268:3085-91. Full Text

115. Hsu CY, Iribarren C, McCulloch CE, Darbinian J, Go AS. Risk factors for end-stage renal disease: 25-year follow-up. Arch Intern Med 2009;169:342-50. Full Text

116. Forman JP, Brenner BM. 'Hypertension' and 'microalbuminuria': the bell tolls for thee. Kidney Int 2006;69:22-8. Full Text

117. Accord Study Group; Cushman WC, Evans GW, et al. Effects of intensive blood-pressure control in type 2 diabetes mellitus. N Engl J Med 2010;362:1575-85. Full Text

118. Berl T, Hunsicker LG, Lewis JB, et al. Impact of achieved blood pressure on cardiovascular outcomes in the Irbesartan Diabetic Nephropathy Trial. J Am Soc Nephrol 2005;16:2170-9. Full Text

119. Cooper-DeHoff RM, Gong Y, Handberg EM, et al. Tight blood pressure control and cardiovascular outcomes among hypertensive patients with diabetes and coronary artery disease. JAMA 2010;304:61-8. Full Text

120. Mancia G. Effects of intensive blood pressure control in the management of patients with type 2 diabetes mellitus in the Action to Control Cardiovascular Risk in Diabetes (ACCORD) trial. Circulation 2010;122: 847-9. Full Text

121. Zanchetti A, Grassi G, Mancia G. When should antihypertensive drug treatment be initiated and to what levels should systolic blood pressure be lowered? A critical reappraisal. J Hypertens 2009;27:923-34. Full Text

122. Ruggenenti P, Perna A, Loriga G, et al. Blood-pressure control for renoprotection in patients with nondiabetic chronic renal disease (REIN-2): multicentre, randomised controlled trial. Lancet 2005;365:939-46. Full Text

123. Verdecchia P, Staessen JA, Angeli F, et al. Usual versus tight control of systolic blood pressure in nondiabetic patients with hypertension (Cardio-Sis): an open-label randomised trial. Lancet 2009;374:52533. Full Text

124. Wuhl E, Trivelli A, Picca S, et al. Strict bloodpressure control and progression of renal failure in children. N Engl J Med 2009;361:1639-50. Full Text

125. Rahman M, Pressel S, Davis BR, et al. Renal outcomes in high-risk hypertensive patients treated with an angiotensin-converting enzyme inhibitor or a calcium channel blocker vs a diuretic: a report from the Antihypertensive and Lipid-Lowering Treatment to Prevent Heart Attack Trial (ALLHAT). Arch Intern Med 2005;165:936-46. Full Text
126. James MT, Hemmelgarn BR, Tonelli M. Early recognition and prevention of chronic kidney disease. Lancet 2010;375:1296-309. Full Text

127. Wilmer WA, Rovin BH, Hebert CJ, Rao SV, Kumor $\mathrm{K}$, Hebert LA. Management of glomerular proteinuria: a commentary. J Am Soc Nephrol 2003;14: 3217-32. Full Text

128. Hebert LA, Wilmer WA, Falkenhain ME, LadsonWofford SE, Nahman NS Jr, Rovin BH. Renoprotection: one or many therapies? Kidney Int 2001;59: 1211-26. Full Text

129. Ruggenenti P, Schieppati A, Remuzzi G. Progression, remission, regression of chronic renal diseases. Lancet 2001;357:1601-8. Full Text

130. Gentile G, Remuzzi G, Ruggenenti P. Dual reninangiotensin system blockade for nephroprotection: still under scrutiny. Nephron 2015;129:39-41. Full $\underline{\text { Text }}$

131. Kronenberg F. Emerging risk factors and markers of chronic kidney disease progression. Nat Rev Nephrol 2009;5:677-89. Full Text

132. Marchand GR. Effect of parathyroid hormone on the determinants of glomerular filtration in dogs. Am J Physiol 1985;248:F482-6.

133. Ogata H, Ritz E, Odoni G, Amann K, Orth SR. Beneficial effects of calcimimetics on progression of renal failure and cardiovascular risk factors. J Am Soc Nephrol 2003;14:959-67. Full Text

134. Kovesdy CP, Ahmadzadeh S, Anderson JE, KalantarZadeh K. Secondary hyperparathyroidism is associated with higher mortality in men with moderate to severe chronic kidney disease. Kidney Int 2008;73: 1296-302. Full Text

135. Schumock GT, Andress DL, Marx SE, Sterz R, Joyce AT, Kalantar-Zadeh K. Association of secondary hyperparathyroidism with CKD progression, health care costs and survival in diabetic predialysis CKD patients. Nephron Clin Pract 2009;113:c54-61. Full $\underline{\text { Text }}$

136. Costa-Hong V, Jorgetti V, Gowdak LH, Moyses RM, Krieger EM, De Lima JJ. Parathyroidectomy reduces cardiovascular events and mortality in renal hyperparathyroidism. Surgery 2007;142:699-703. Full $\underline{\text { Text }}$

137. Alfrey AC. The role of abnormal phosphorus metabolism in the progression of chronic kidney disease and metastatic calcification. Kidney Int Suppl 2004:S13-17. Full Text

138. Loghman-Adham M. Role of phosphate retention in the progression of renal failure. J Lab Clin Med 1993;122:16-26. 
139. Ritz E, Gross ML, Dikow R. Role of calciumphosphorous disorders in the progression of renal failure. Kidney Int Suppl 2005:S66-70. Full Text

140. Norris KC, Greene T, Kopple J, et al. Baseline predictors of renal disease progression in the African American Study of Hypertension and Kidney Disease. J Am Soc Nephrol 2006;17:2928-36. Full $\underline{\text { Text }}$

141. Schwarz S, Trivedi BK, Kalantar-Zadeh K, Kovesdy CP. Association of disorders in mineral metabolism with progression of chronic kidney disease. Clin J Am Soc Nephrol 2006;1:825-31. Full Text

142. Fliser D, Kollerits B, Neyer U, et al. Fibroblast growth factor 23 (FGF23) predicts progression of chronic kidney disease: the Mild to Moderate Kidney Disease (MMKD) Study. J Am Soc Nephrol 2007;18:2600-8. Full Text

143. Voormolen N, Noordzij M, Grootendorst DC, et al. High plasma phosphate as a risk factor for decline in renal function and mortality in pre-dialysis patients. Nephrol Dial Transplant 2007;22:2909-16. Full $\underline{\text { Text }}$

144. Levin A, Djurdjev O, Beaulieu M, Er L. Variability and risk factors for kidney disease progression and death following attainment of stage 4 CKD in a referred cohort. Am J Kidney Dis 2008;52:661-71. Full Text

145. Noori N, Sims JJ, Kopple JD, et al. Organic and inorganic dietary phosphorus and its management in chronic kidney disease. Iran J Kidney Dis 2010;4: 89-100.

146. Ibels LS, Alfrey AC, Haut L, Huffer WE. Preservation of function in experimental renal disease by dietary restriction of phosphate. N Engl J Med 1978;298: 122-6. Full Text

147. Cozzolino M, Staniforth ME, Liapis H, et al. Sevelamer hydrochloride attenuates kidney and cardiovascular calcifications in long-term experimental uremia. Kidney Int 2003;64:1653-61. Full Text

148. Nagano N, Miyata S, Obana S, et al. Sevelamer hydrochloride, a phosphate binder, protects against deterioration of renal function in rats with progressive chronic renal insufficiency. Nephrol Dial Transplant 2003;18:2014-23. Full Text

149. Block GA, Klassen PS, Lazarus JM, Ofsthun N, Lowrie EG, Chertow GM. Mineral metabolism, mortality, and morbidity in maintenance hemodialysis. J Am Soc Nephrol 2004;15:2208-18. Full Text

150. Kestenbaum B, Sampson JN, Rudser KD, et al. Serum phosphate levels and mortality risk among people with chronic kidney disease. J Am Soc Nephrol 2005;16:520-8. Full Text
151. Stavroulopoulos A, Porter CJ, Pointon K, Monaghan JM, Roe SD, Cassidy MJ. Evolution of coronary artery calcification in patients with chronic kidney disease Stages 3 and 4, with and without diabetes. Nephrol Dial Transplant 2011;26:2582-9. Full Text

152. Ix JH, De Boer IH, Peralta CA, et al. Serum phosphorus concentrations and arterial stiffness among individuals with normal kidney function to moderate kidney disease in MESA. Clin J Am Soc Nephrol 2009;4:609-15. Full Text

153. Tonelli M, Sacks F, Pfeffer M, Gao Z, Curhan G. Relation between serum phosphate level and cardiovascular event rate in people with coronary disease. Circulation 2005;112:2627-33. Full Text

154. de Boer IH, Rue TC, Kestenbaum B. Serum phosphorus concentrations in the third National Health and Nutrition Examination Survey (NHANES III). Am J Kidney Dis 2009;53:399-407. Full Text

155. Dhingra R, Sullivan LM, Fox CS, et al. Relations of serum phosphorus and calcium levels to the incidence of cardiovascular disease in the community. Arch Intern Med 2007;167:879-85. Full Text

156. Foley RN, Collins AJ, Ishani A, Kalra PA. Calciumphosphate levels and cardiovascular disease in community-dwelling adults: the Atherosclerosis Risk in Communities (ARIC) Study. Am Heart J 2008;156: 556-63. Full Text

157. Foley RN, Collins AJ, Herzog CA, Ishani A, Kalra PA. Serum phosphorus levels associate with coronary atherosclerosis in young adults. J Am Soc Nephrol 2009;20:397-404. Full Text

158. Foley RN, Collins AJ, Herzog CA, Ishani A, Kalra PA. Serum phosphate and left ventricular hypertrophy in young adults: the coronary artery risk development in young adults study. Kidney Blood Press Res 2009; 32:37-44. Full Text

159. Chonchol M, Dale R, Schrier RW, Estacio R. Serum phosphorus and cardiovascular mortality in type 2 diabetes. Am J Med 2009;122:380-6. Full Text

160. Mehrotra R, Kermah D, Fried L, Adler S, Norris K. Racial differences in mortality among those with CKD. J Am Soc Nephrol 2008;19:1403-10. Full Text

161. Dawson-Hughes B. Racial/ethnic considerations in making recommendations for vitamin $\mathrm{D}$ for adult and elderly men and women. Am J Clin Nutr 2004;80:1763S-6S.

162. Nesby-O’Dell S, Scanlon KS, Cogswell ME, et al. Hypovitaminosis D prevalence and determinants among African American and white women of reproductive age: third National Health and Nutrition Examination Survey, 1988-1994. Am J Clin Nutr 2002;76:187-92. 
163. Bell NH, Epstein S, Greene A, Shary J, Oexmann MJ, Shaw S. Evidence for alteration of the vitamin D-endocrine system in obese subjects. J Clin Invest 1985;76:370-3. Full Text

164. Wolf M, Shah A, Gutierrez O, et al. Vitamin D levels and early mortality among incident hemodialysis patients. Kidney Int 2007;72:1004-13. Full Text

165. Gupta A, Kallenbach LR, Zasuwa G, Divine GW. Race is a major determinant of secondary hyperparathyroidism in uremic patients. J Am Soc Nephrol 2000;11:330-4.

166. Sawaya BP, Butros R, Naqvi S, et al. Differences in bone turnover and intact PTH levels between African American and Caucasian patients with end-stage renal disease. Kidney Int 2003;64:737-42. Full Text

167. Gutierrez OM, Isakova T, Andress DL, Levin A, Wolf M. Prevalence and severity of disordered mineral metabolism in Blacks with chronic kidney disease. Kidney Int 2008;73:956-62. Full Text

168. Gutierrez OM, Isakova T, Smith K, Epstein M, Patel $\mathrm{N}$, Wolf $\mathrm{M}$. Racial differences in postprandial mineral ion handling in health and in chronic kidney disease. Nephrol Dial Transplant 2010;25:3970-7. Full Text

169. Kestenbaum B, Glazer NL, Kottgen A, et al. Common genetic variants associate with serum phosphorus concentration. J Am Soc Nephrol 2010;21:1223-32. Full Text

170. A randomized trial of propranolol in patients with acute myocardial infarction. I. Mortality results. JAMA 1982;247:1707-14. Full Text

171. Beck L, Karaplis AC, Amizuka N, Hewson AS, Ozawa $\mathrm{H}$, Tenenhouse HS. Targeted inactivation of Npt2 in mice leads to severe renal phosphate wasting, hypercalciuria, and skeletal abnormalities. Proc Natl Acad Sci U S A 1998;95:5372-7. Full Text

172. Segawa H, Onitsuka A, Kuwahata M, et al. Type IIc sodium-dependent phosphate transporter regulates calcium metabolism. J Am Soc Nephrol 2009;20: 104-13. Full Text

173. Magen D, Berger L, Coady MJ, et al. A loss-of-function mutation in NaPi-IIa and renal Fanconi's syndrome. N Engl J Med 2010;362:1102-9. Full Text

174. Schlingmann KP, Ruminska J, Kaufmann M, et al. Autosomal-recessive mutations in SLC34A1 encoding sodium-phosphate cotransporter 2A cause idiopathic infantile hypercalcemia. J Am Soc Nephrol 2015 Jun 5 [Epub ahead of print]. Full Text

175. Rajagopal A, Braslavsky D, Lu JT, et al. Exome sequencing identifies a novel homozygous mutation in the phosphate transporter SLC34A1 in hypophos- phatemia and nephrocalcinosis. J Clin Endocrinol Metab 2014;99:E2451-6. Full Text

176. Kottgen A, Pattaro C, Boger CA, et al. New loci associated with kidney function and chronic kidney disease. Nat Genet 2010;42:376-84. Full Text

177. Oakes SA, Papa FR. The role of the endoplasmic reticulum stress in human pathology. Annu Rev Path 2015;10:173-94. Full Text

178. Kuhlmann A, Haas CS, Gross ML, et al. 1,25Dihydroxyvitamin D3 decreases podocyte loss and podocyte hypertrophy in the subtotally nephrectomized rat. Am J Physiol Renal Physiol 2004;286: F526-33. Full Text

179. Branisteanu DD, Leenaerts $P$, van Damme B, Bouillon R. Partial prevention of active Heymann nephritis by 1 alpha, 25 dihydroxyvitamin D3. Clin Exp Immunol 1993;94:412-17. Full Text

180. Hirata M, Makibayashi K, Katsumata K, et al. 22Oxacalcitriol prevents progressive glomerulosclerosis without adversely affecting calcium and phosphorus metabolism in subtotally nephrectomized rats. Nephrol Dial Transplant 2002;17:2132-7. Full Text

181. Piecha G, Kokeny G, Nakagawa K, et al. Calcimimetic R-568 or calcitriol: equally beneficial on progression of renal damage in subtotally nephrectomized rats. Am J Physiol Renal Physiol 2008;294: F748-57. Full Text

182. Coen G, Mazzaferro S, Manni M, et al. No acceleration and possibly slower progression of renal failure during calcitriol treatment in predialysis chronic renal failure. Nephrol Dial Transplant 1994;9:1520.

183. Thomas MC, Cooper ME. Into the light? Diabetic nephropathy and vitamin D. Lancet 2010;376:15212. Full Text

184. Alborzi P, Patel NA, Peterson C, et al. Paricalcitol reduces albuminuria and inflammation in chronic kidney disease: a randomized double-blind pilot trial. Hypertension 2008;52:249-55. Full Text

185. Agarwal R, Acharya M, Tian J, et al. Antiproteinuric effect of oral paricalcitol in chronic kidney disease. Kidney Int 2005;68:2823-8. Full Text

186. Fishbane S, Chittineni H, Packman M, Dutka P, Ali $\mathrm{N}$, Durie N. Oral paricalcitol in the treatment of patients with CKD and proteinuria: a randomized trial. Am J Kidney Dis 2009;54:647-52. Full Text

187. Tan X, Wen X, Liu Y. Paricalcitol inhibits renal inflammation by promoting vitamin $\mathrm{D}$ receptormediated sequestration of NF-kappaB signaling. $\mathrm{J}$ Am Soc Nephrol 2008;19:1741-52. Full Text 
188. Mizobuchi M, Morrissey J, Finch JL, et al. Combination therapy with an angiotensin-converting enzyme inhibitor and a vitamin D analog suppresses the progression of renal insufficiency in uremic rats. $J$ Am Soc Nephrol 2007;18:1796-806. Full Text

189. de Zeeuw D, Agarwal R, Amdahl M, et al. Selective vitamin $\mathrm{D}$ receptor activation with paricalcitol for reduction of albuminuria in patients with type 2 diabetes (VITAL study): a randomised controlled trial. Lancet 2010;376:1543-51. Full Text

190. Levin A, Bakris GL, Molitch M, et al. Prevalence of abnormal serum vitamin D, PTH, calcium, and phosphorus in patients with chronic kidney disease: results of the study to evaluate early kidney disease. Kidney Int 2007;71:31-8. Full Text

191. Ravani P, Malberti F, Tripepi G, et al. Vitamin D levels and patient outcome in chronic kidney disease. Kidney Int 2009;75:88-95. Full Text

192. Kovesdy CP, Ahmadzadeh S, Anderson JE, KalantarZadeh K. Association of activated vitamin D treatment and mortality in chronic kidney disease. Arch Intern Med 2008;168:397-403. Full Text

193. Teng M, Wolf M, Lowrie E, Ofsthun N, Lazarus JM, Thadhani R. Survival of patients undergoing hemodialysis with paricalcitol or calcitriol therapy. N Engl J Med 2003;349:446-56. Full Text

194. Palmer SC, McGregor DO, Macaskill P, Craig JC, Elder GJ, Strippoli GF. Meta-analysis: vitamin D compounds in chronic kidney disease. Ann Intern Med 2007;147:840-53. Full Text

195. Palmer SC, McGregor DO, Craig JC, Elder G, Macaskill P, Strippoli GF. Vitamin D compounds for people with chronic kidney disease not requiring dialysis. Cochrane Database Syst Rev 2009;(4): CDoo8175. Full Text

196. Palmer SC, McGregor DO, Craig JC, Elder G, Macaskill P, Strippoli GF. Vitamin D compounds for people with chronic kidney disease requiring dialysis. Cochrane Database Syst Rev 2009;(4): CDoo5633. Full Text

197. Al-Aly Z. Vitamin D as a novel nontraditional risk factor for mortality in hemodialysis patients: the need for randomized trials. Kidney Int 2007;72:909-11. Full Text

198. Gutierrez OM. Fibroblast growth factor 23 and disordered vitamin $\mathrm{D}$ metabolism in chronic kidney disease: updating the "trade-off" hypothesis. Clin J Am Soc Nephrol 2010;5:1710-16. Full Text

199. Juppner H, Wolf M, Salusky IB. FGF-23: more than a regulator of renal phosphate handling? $\mathrm{J}$ Bone Miner Res 2010;25:2091-7. Full Text
200. Liu S, Quarles LD. How fibroblast growth factor 23 works. J Am Soc Nephrol 2007;18:1637-47. Full Text

201. Wahl P, Wolf M. FGF23 in chronic kidney disease. Adv Exp Med Biol 2012;728:107-25. Full Text

202. Gutierrez O, Isakova $\mathrm{T}$, Rhee $\mathrm{E}$, et al. Fibroblast growth factor-23 mitigates hyperphosphatemia but accentuates calcitriol deficiency in chronic kidney disease. J Am Soc Nephrol 2005;16:2205-15. Full Text

203. Shigematsu T, Kazama JJ, Yamashita T, et al. Possible involvement of circulating fibroblast growth factor 23 in the development of secondary hyperparathyroidism associated with renal insufficiency. Am J Kidney Dis 2004;44:250-6. Full Text

204. Seiler S, Reichart B, Roth D, Seibert E, Fliser D, Heine GH. FGF-23 and future cardiovascular events in patients with chronic kidney disease before initiation of dialysis treatment. Nephrol Dial Transplant 2010;25:3983-9. Full Text

205. Gutierrez OM, Mannstadt M, Isakova T, et al. Fibroblast growth factor 23 and mortality among patients undergoing hemodialysis. N Engl J Med 2008;359: 584-92. Full Text

206. Jean G, Terrat JC, Vanel T, et al. High levels of serum fibroblast growth factor (FGF)-23 are associated with increased mortality in long haemodialysis patients. Nephrol Dial Transplant 2009;24:2792-6. $\underline{\text { Full Text }}$

207. Nasrallah MM, El-Shehaby AR, Salem MM, Osman NA, El Sheikh E, Sharaf El Din UA. Fibroblast growth factor-23 (FGF-23) is independently correlated to aortic calcification in haemodialysis patients. Nephrol Dial Transplant 2010;25:2679-85. Full Text

208. Gutierrez OM, Januzzi JL, Isakova T, et al. Fibroblast growth factor 23 and left ventricular hypertrophy in chronic kidney disease. Circulation 2009; 119:2545-52. Full Text

209. Wesseling-Perry K, Pereira RC, Wang H, et al. Relationship between plasma fibroblast growth factor-23 concentration and bone mineralization in children with renal failure on peritoneal dialysis. J Clin Endocrinol Metab 2009;94:511-17. Full Text

210. Gutierrez OM, Wolf M. Dietary phosphorus restriction in advanced chronic kidney disease: merits, challenges, and emerging strategies. Semin Dial 2010;23:401-6. Full Text

211. Oliveira RB, Cancela AL, Graciolli FG, et al. Early control of PTH and FGF23 in normophosphatemic CKD patients: a new target in CKD-MBD therapy? Clin J Am Soc Nephrol 2010;5:286-91. Full Text 
212. Muller D, Mehling H, Otto B, et al. Niacin lowers serum phosphate and increases HDL cholesterol in dialysis patients. Clin J Am Soc Nephrol 2007;2: 1249-54. Full Text

213. Wetmore JB, Liu S, Krebill R, Menard R, Quarles LD. Effects of cinacalcet and concurrent low-dose vitamin D on FGF23 levels in ESRD. Clin J Am Soc Nephrol 2010;5:110-16. Full Text

214. Nishi H, Nii-Kono T, Nakanishi S, et al. Intravenous calcitriol therapy increases serum concentrations of fibroblast growth factor-23 in dialysis patients with secondary hyperparathyroidism. Nephron Clin Pract 2005;101:c94-9. Full Text

215. Tomoe Y, Segawa H, Shiozawa K, et al. Phosphaturic action of fibroblast growth factor 23 in Npt2 null mice. Am J Physiol Renal Physiol 2010;298:F134150. Full Text

216. Farrow EG, Davis SI, Summers LJ, White KE. Initial FGF23-mediated signaling occurs in the distal convoluted tubule. J Am Soc Nephrol 2009;20:9556o. Full Text

217. Saito A, Kaseda R, Hosojima M, Sato H. Proximal tubule cell hypothesis for cardiorenal syndrome in diabetes. Int J Nephrol 2011;2011:957164. Full Text

218. Mirza MA, Alsio J, Hammarstedt A, et al. Circulating fibroblast growth factor-23 is associated with fat mass and dyslipidemia in two independent cohorts of elderly individuals. Arterioscler Thromb Vasc Biol 2011;31:219-27. Full Text

219. Frankenfield DL, Rocco MV, Roman SH, McClellan WM. Survival advantage for adult Hispanic hemodialysis patients? Findings from the end-stage renal disease clinical performance measures project. J Am Soc Nephrol 2003;14:180-6. Full Text

220. Wolf M, Betancourt J, Chang Y, et al. Impact of activated vitamin $\mathrm{D}$ and race on survival among hemodialysis patients. J Am Soc Nephrol 2008;19:137988. Full Text

221. Isakova $\mathrm{T}$, Ix $\mathrm{JH}$, Sprague $\mathrm{SM}$, et al. Rationale and approaches to phosphate and fibroblast growth factor 23 reduction in CKD. J Am Soc Nephrol 2015 May 12. pii: ASN.2015020117. [Epub ahead of print].

222. Hurt RT, Kulisek C, Buchanan LA, McClave SA. The obesity epidemic: challenges, health initiatives, and implications for gastroenterologists. Gastroenterol Hepatol (N Y) 2010;6:780-92.

223. Olshansky SJ, Passaro DJ, Hershow RC, et al. A potential decline in life expectancy in the United States in the 21st century. N Engl J Med 2005;352: 1138-45. Full Text

224. Guh DP, Zhang W, Bansback N, Amarsi Z, Birmingham CL, Anis AH. The incidence of co- morbidities related to obesity and overweight: a systematic review and meta-analysis. BMC Public Health 2009;9:88. Full Text

225. Pi-Sunyer X. The medical risks of obesity. Postgrad Med 2009;121:21-33. Full Text

226. McAllister EJ, Dhurandhar NV, Keith SW, et al. Ten putative contributors to the obesity epidemic. Crit Rev Food Sci Nutr 2009;49:868-913. Full Text

227. Mozaffarian D, Katan MB, Ascherio A, Stampfer MJ, Willett WC. Trans fatty acids and cardiovascular disease. N Engl J Med 2006;354:1601-13. Full Text

228. Mente A, de Koning L, Shannon HS, Anand SS. A systematic review of the evidence supporting a causal link between dietary factors and coronary heart disease. Arch Intern Med 2009;169:659-69. $\underline{\text { Full Text }}$

229. Mozaffarian D, Aro A, Willett WC. Health effects of trans-fatty acids: experimental and observational evidence. Eur J Clin Nutr 2009;63(Suppl 2):S5-21. Full Text

230. Stanhope KL, Schwarz JM, Keim NL, et al. Consuming fructose-sweetened, not glucose-sweetened, beverages increases visceral adiposity and lipids and decreases insulin sensitivity in overweight/obese humans. J Clin Invest 2009;119:1322-34. Full Text

231. Tappy L, Le KA. Metabolic effects of fructose and the worldwide increase in obesity. Physiol Rev 2010;90: 23-46. Full Text

232. Yang Q. Gain weight by "going diet?" Artificial sweeteners and the neurobiology of sugar cravings: neuroscience 2010. Yale J Biol Med 2010;83:101-8.

233. Smeets PA, de Graaf C, Stafleu A, van Osch MJ, van der Grond J. Functional magnetic resonance imaging of human hypothalamic responses to sweet taste and calories. Am J Clin Nutr 2005;82:1011-16.

234. de Araujo IE, Oliveira-Maia AJ, Sotnikova TD, et al. Food reward in the absence of taste receptor signaling. Neuron 2008;57:930-41. Full Text

235. Cui M, Jiang P, Maillet E, Max M, Margolskee RF, Osman R. The heterodimeric sweet taste receptor has multiple potential ligand binding sites. Curr Pharm Des 2006;12:4591-600. Full Text

236. Ogden CL, Yanovski SZ, Carroll MD, Flegal KM. The epidemiology of obesity. Gastroenterology 2007;132:2087-102. Full Text

237. Nguyen S, Hsu CY. Excess weight as a risk factor for kidney failure. Curr Opin Nephrol Hypertens 2007; 16:71-6. Full Text

238. Hsu CY, McCulloch CE, Iribarren C, Darbinian J, Go AS. Body mass index and risk for end-stage renal disease. Ann Intern Med 2006;144:21-8. Full Text 
239. Yusuf S, Hawken S, Ounpuu S, et al. Obesity and the risk of myocardial infarction in 27,000 participants from 52 countries: a case-control study. Lancet 2005;366:1640-9. Full Text

240. Ejerblad E, Fored CM, Lindblad P, Fryzek J, McLaughlin JK, Nyren O. Obesity and risk for chronic renal failure. J Am Soc Nephrol 2006;17: 1695-702. Full Text

241. Pinto-Sietsma SJ, Navis G, Janssen WM, de Zeeuw D, Gans RO, de Jong PE. A central body fat distribution is related to renal function impairment, even in lean subjects. Am J Kidney Dis 2003;41:733-41. Full $\underline{\text { Text }}$

242. Kambham N, Markowitz GS, Valeri AM, Lin J, D'Agati VD. Obesity-related glomerulopathy: an emerging epidemic. Kidney Int 2001;59:1498-509. Full Text

243. Griffin KA, Kramer H, Bidani AK. Adverse renal consequences of obesity. Am J Physiol Renal Physiol 2008;294:F685-96. Full Text

244. Kovesdy CP, Anderson JE. Reverse epidemiology in patients with chronic kidney disease who are not yet on dialysis. Semin Dial 2007;20:566-9.

245. Evans M, Fryzek JP, Elinder CG, et al. The natural history of chronic renal failure: results from an unselected, population-based, inception cohort in Sweden. Am J Kidney Dis 2005;46:863-70. Full Text

246. Kovesdy CP, Anderson JE, Kalantar-Zadeh K. Paradoxical association between body mass index and mortality in men with CKD not yet on dialysis. Am J Kidney Dis 2007;49:581-91. Full Text

247. Peralta CA, Kurella M, Lo JC, Chertow GM. The metabolic syndrome and chronic kidney disease. Curr Opin Nephrol Hypertens 2006;15:361-5. Full $\underline{\text { Text }}$

248. Chen J, Muntner P, Hamm LL, et al. The metabolic syndrome and chronic kidney disease in U.S. adults. Ann Intern Med 2004;140:167-74. Full Text

249. Joles JA, Kunter U, Janssen U, et al. Early mechanisms of renal injury in hypercholesterolemic or hypertriglyceridemic rats. J Am Soc Nephrol 2000;11:669-83.

250. Lin J, Judd S, Le A, et al. Associations of dietary fat with albuminuria and kidney dysfunction. Am J Clin Nutr 2010;92:897-904. Full Text

251. Johnson RJ, Sanchez-Lozada LG, Nakagawa T. The effect of fructose on renal biology and disease. $\mathrm{J} \mathrm{Am}$ Soc Nephrol 2010;21:2036-9. Full Text

252. Gersch MS, Mu W, Cirillo P, et al. Fructose, but not dextrose, accelerates the progression of chronic kidney disease. Am J Physiol Renal Physiol 2007;293: F1256-61. Full Text
253. Nguyen S, Choi HK, Lustig RH, Hsu CY. Sugarsweetened beverages, serum uric acid, and blood pressure in adolescents. J Pediatr 2009;154:807-13. $\underline{\text { Full Text }}$

254. Lin J, Curhan GC. Associations of sugar and artificially sweetened soda with albuminuria and kidney function decline in women. Clin J Am Soc Nephrol 2011;6:160-6. Full Text

255. Alexander MP, Patel TV, Farag YM, Florez A, Rennke HG, Singh AK. Kidney pathological changes in metabolic syndrome: a cross-sectional study. Am J Kidney Dis 2009;53:751-9. Full Text

256. Welsh GI, Hale LJ, Eremina V, et al. Insulin signaling to the glomerular podocyte is critical for normal kidney function. Cell Metab 2010;12:32940. Full Text

257. Fornoni A. Proteinuria, the podocyte, and insulin resistance. N Engl J Med 2010;363:2068-9. Full Text

258. de Boer IH; DCCT EDIC Research Group. Kidney disease and related findings in the diabetes control and complications trial/epidemiology of diabetes interventions and complications study. Diabetes Care 2014;37:24-30. Full Text

259. Intensive blood-glucose control with sulphonylureas or insulin compared with conventional treatment and risk of complications in patients with type 2 diabetes (UKPDS 33). UK Prospective Diabetes Study (UKPDS) Group. Lancet 1998;352:837-53. Full Text

260. Ohkubo Y, Kishikawa H, Araki E, et al. Intensive insulin therapy prevents the progression of diabetic microvascular complications in Japanese patients with non-insulin-dependent diabetes mellitus: a randomized prospective 6-year study. Diabetes Res Clin Pract 1995;28:103-17. Full Text

261. Zoungas S, Chalmers J, Neal B, et al. Follow-up of blood-pressure lowering and glucose control in type 2 diabetes. N Engl J Med 2014;371:1392-406. Full Text

262. Ismail-Beigi F, Craven T, Banerji MA, et al. Effect of intensive treatment of hyperglycaemia on microvascular outcomes in type 2 diabetes: an analysis of the ACCORD randomised trial. Lancet 2010;376: 419-30. Full Text

263. Hemmingsen B, Lund SS, Gluud C, et al. Targeting intensive glycaemic control versus targeting conventional glycaemic control for type 2 diabetes mellitus. Cochrane Database Syst Rev 2013;11:CDoo8143.

264. Inzucchi SE, Bergenstal RM, Buse JB, et al. Management of hyperglycemia in type 2 diabetes: a patientcentered approach: position statement of the American Diabetes Association (ADA) and the 
European Association for the Study of Diabetes (EASD). Diabetes Care 2012;35:1364-79. Full Text

265. American Diabetes Association. Standards of medical care in diabetes--2014. Diabetes Care 2014;37 (Suppl 1):S14-80. Full Text

266. Feig DI. Uric acid: a novel mediator and marker of risk in chronic kidney disease? Curr Opin Nephrol Hypertens 2009;18:526-30. Full Text

267. Ben-Dov IZ, Kark JD. Serum uric acid is a GFRindependent long-term predictor of acute and chronic renal insufficiency: the Jerusalem Lipid Research Clinic cohort study. Nephrol Dial Transplant 2011;26:2558-66. Full Text

268. Kanji T, Gandhi M, Clase CM, Yang R. Urate lowering therapy to improve renal outcomes in patients with chronic kidney disease: systematic review and meta-analysis. BMC Nephrol 2015;16:58. Full Text

269. Kovesdy CP, Kalantar-Zadeh K. Oral bicarbonate: renoprotective in CKD? Nat Rev Nephrol 2010;6:157. Full Text

270. Kraut JA, Madias NE. Consequences and therapy of the metabolic acidosis of chronic kidney disease. Pediatr Nephrol 2011;26:19-28. Full Text
271. Driver TH, Shlipak MG, Katz R, et al. Low serum bicarbonate and kidney function decline: the MultiEthnic Study of Atherosclerosis (MESA). Am J Kidney Dis 2014;64:534-41. Full Text

272. Goldenstein L, Driver TH, Fried LF, et al. Serum bicarbonate concentrations and kidney disease progression in community-living elders: the Health, Aging, and Body Composition (Health ABC) Study. Am J Kidney Dis 2014;64:542-9. Full Text

273. Lo LJ, Go AS, Chertow GM, et al. Dialysis-requiring acute renal failure increases the risk of progressive chronic kidney disease. Kidney Int 2009;76:893-9. Full Text

274. Liu KD. Acute kidney injury: is acute kidney injury a risk factor for long-term mortality? Nat Rev Nephrol 2010;6:389-91. Full Text

275. Oparil S, Schmieder RE. New approaches in the treatment of hypertension. Circ Res 2015;116:107495. Full Text 